\title{
A BIBLIOMETRIC REVIEW OF RESEARCH ON VENTURE CAPITAL
}

\author{
Mohamed Cherif Benzouai and Khalid Djeffal* \\ Department of Finance and Accounting, INFI Laboratory, \\ Oum El Bouaghi University, Algeria \\ *Corresponding author: djeffal.khaled@univ-oeb.dz
}

Published online: 4 June 2021

To cite this article: Benzouai, M. C., \& Djeffal, K. (2021). A bibliometric review of research on venture capital. Asian Academy of Management Journal, 26(1), 47-88. https:// doi.org/10.21315/aamj2021.26.1.3

To link to this article: https://doi.org/10.21315/aamj2021.26.1.3

\begin{abstract}
Venture capital is a cross-cutting discipline and research field. This study used bibliometric indicators of publications indexed in Web of Science (WOS) Core Collection over the last two decades to provide an overview of the main characteristics of its publications. A total of 1,840 papers by 2,607 authors in 518 journals were reviewed. The publications were examined in terms of temporal trend, geographical and institutional distribution, references, authors, and citations. The results indicate that the importance of venture capital research is increasing. In terms of impact, a small group of productive countries (e.g., USA and UK) and authors (e.g., Cumming and Wright) contributed to a significant share of these publications. Whereas China is expected to attract more attention to this topic in the future. Harvard University is the most productive institution and the Journal of Business Venturing is the most active journal. By topic, publications that address the contribution of venture capital to entrepreneurship are the most cited. New areas of research have focused especially on the implication of signal theory in venture capital networks, support for decision-makers and crowdfunding as a new investment strategy. Today, the microlevel is the dominant level (compared to the macro-level) in venture capital research. The results of this study aim to contribute to supporting decision making in a venture capital research management context and to serve as a guide for future researchers or evaluators.
\end{abstract}

Keywords: bibliometric analysis, venture capital, research management, authors cooperation, citation analysis

(C) Asian Academy of Management and Penerbit Universiti Sains Malaysia, 2021. This work is licensed under the terms of the Creative Commons Attribution (CC BY) (http://creativecommons. org/licenses/by/4.0/). 


\section{INTRODUCTION}

The impact of venture business on economic growth has long been the subject of debate among academics (Timmons \& Bygrave, 1986; Barry et al., 1990; Lerner, 1995; Gompers \& Lerner, 1998; Houben \& Kakes, 2002; Samila \& Sorenson, 2011). This debate still very recent and has focused on new issues (Pradhan et al., 2018; Rizvi \& Arshad, 2018; Dettenhofer et al., 2019). The importance of these ventures is related to venture capital as an essential funding tool of all investments based on new ideas (Florida \& Smith Jr, 1990; Kortum \& Lerner, 1998, 2000; Dushnitsky \& Lenox, 2005; Rossi \& Martini, 2019; González-Uribe, 2020; Que $\&$ Zhang, 2020). In 50 years of development, a large number of studies on venture capital in various aspects have emerged around the world and have contributed with different definitions and characteristics (Landström, 2007).

\section{Overview of Venture Capital}

Venture capital is defined as equity-linked investments in which investors support entrepreneurs by providing the funds and management skills needed to exploit market opportunities for long-term profits (Kortum \& Lerner, 1998). There are generally three types of venture capital: (1) angel investors, typically, wealthy individuals who provide financing to entrepreneurs in exchange for an equity stake in the company (Prowse, 1998; Mitteness et al., 2012); (2) strategic venture capital, also known as corporate venture capital. This form of venture capital allows non-financial corporations to invest in ventures close to their core activities. Most of those investments have strategic goals, usually to obtain access to new technologies and innovations (Dushnitsky \& Lenox, 2005; Wonglimpiyarat, 2016; Rossi et al., 2019a). The third type is the (3) financial venture capital; this type of venture capital, unlike corporate venture capital, has more than one general partner, whose main objective is to have a good return on investment to satisfy its investors (general partners), for which they will try to achieve good exits through an initial public offering (IPO) or mergers (Zider, 1998; Lee \& Wahal, 2004).

Venture capital is also a form of private equity financing that is provided by venture capital firms or funds. The latter acts as a mediator between the funding sources (mainly institutional investors) and entrepreneurial projects that are characterised by rapid growth and high technology (Cumming \& Johan, 2013). These firms invest in businesses of all sizes in several sectors. Nevertheless, most of them are only involved in businesses in particular phases and specific domains (Elango et al., 1995). These characteristics of venture capital financing allow to classify a wide range of these firms according to their investment stage. The investment stage involves seed capital (first phase), start-up, early and middle stage. 
Furthermore, venture capital firms are complex agents, and their value depends on their ability to interact with others through multiplex functions (Ferrary \& Granovetter, 2009). The main functions that have sorted in venture capital research include financing, selecting, collective learning function, signaling function, and embedding function. Financing is the best known economic function (Gompers \& Lerner, 2004; Ferrary \& Granovetter, 2009). Venture capital firms fund entrepreneurial firms in exchange for returns on equity and incur high financial risk, unlike banks and financial markets, which do not lend money to this type of investment due to a lack of assets and a high level of risk exposure (Baldi et al., 2015). Regarding the selecting function, venture capital firms try to fund the most promising projects because their profits depend on the performance of their investments (Brander et al., 2002; Knockaert et al., 2010). Out of more than 500 business plans received per year, only three or four start-ups will be funded (Ferrary \& Granovetter, 2009).

As far as the collective learning function is concerned, over the years, venture capital firms have accumulated considerable knowledge on the creation and development of entrepreneurial businesses, evaluating thousands of projects, funding them and accompanying dozens of start-ups. They have in-depth knowledge of industrial, technological, legal, and managerial issues (Brander et al., 2002; Ferrary \& Granovetter, 2009). They can also exploit their knowledge to adopt financial strategy behaviours in supporting innovations (Minola \& Giorgino, 2008; Rossi et al., 2017; Rossi et al., 2019a; Rossi et al., 2020a; Ma, 2020) and can act ambidextrously in venturing investments (Ferrary, 2011; Hill \& Birkinshaw, 2014; Rossi et al., 2019b; Rossi et al., 2020b).

Another function is the signaling function, which means that start-ups funded by a venture capital firm are a positive signal to other agents in the venture capital firm network because of their high-status and encourages these agents to establish links with it (Newman, 2003). Finally, the embedding function means that venture capital firms are deeply embedded in the business network, embedding entrepreneurs in the businesses they support and providing with access to information, resources, service providers, and business partners through their investors (Ferrary \& Granovetter, 2009).

Venture capital research has two levels of analysis: micro and macro. Initially, academics specialising in micro-level analysis seek to explore venture capital implementation strategies, entrepreneurial behaviour and the relationship between venture capital firms, institutional investors, and entrepreneurs. At this level, research has focused on specific topics such as project selection. For instance, Ueda (2004), who studied a signal model, explained the difference between banks 
and venture capital firms in terms of project evaluation and selection, performance of entrepreneurial investee firms, how venture capital firms implement good governance of their investment portfolio, contracting, and agency issues.

Meuleman et al. (2017) referred to syndication among venture capital firms and alliance strategies. Furthermore, Hellmann (2006) illustrated the case of initial public offerings (IPOs). On the other hand, research at the macro-level has mainly focused on the venture capital economic impact on the structure of the national economy and its different variables. The latter have been a discussion topic for several academics to determine the main elements affecting the national economy. Thus, Gompers and Lerner (1998), Timmons and Bygrave (1986), and Pruthi and Wright (2019) have argued that government policies, entrepreneurship, economic growth, innovation, financial markets, internationalisation, and job creation are the main components of any economy. Gilson (2002) pointed out that the venture capital industry in the USA has developed through market forces, unlike the rest of the world. Nevertheless, they have made great efforts to engineer their venture capital market. To this end, this study examines how countries can establish their venture capital market by addressing three foundations: the entrepreneur, the financial intermediary, and the capital.

\section{Research Presentation, Objectives and Value}

Venture capital research encompasses a wide range of academic disciplines such as finance, management, economics, law, and sociology (Cornelius \& Persson, 2006; Cancino et al., 2018). The involvement of academics from different disciplines further encourages the venture capital topic to expand and grow. This capacity for growth requires an ongoing review on the evolution of research in this topic. Consequently some studies have reviewed the existing literature on venture capital and identified the major research streams in terms of internationalisation (Wright et al., 2005; Park et al., 2015; Devigne et al., 2018) and the key considerations relevant to the venture financing domain to understand this phenomenon (Wright Robbie, 1998; Wood \& Wright, 2009; Narayanan et al., 2009; Cumming \& Zhang, 2016; Drover et al., 2017; Köhn, 2018; Harrison \& Mason, 2019).

Current knowledge of bibliometric analyses regarding venture capital is scarce. There have been only a few recent studies that present the evolution of venture capital research using bibliometric analysis (Cornelius \& Persson, 2006; Cancino et al., 2018; Tenca et al., 2018; Reverte \& Badillo, 2019). Although previous research has covered some perspectives of bibliometric analysis, others have received scant attention. In the three most recent bibliometric studies, Reverte and Badillo (2019) focused on alternative equity financing, where venture capital is 
part of the analysis, and the field research is limited to the business economics domain in the selection of the database. Tenca et al. (2018) focused on business angels, which is informal venture capital, and the field research is also limited to the business economics domain. The study of Cancino et al. (2018) focused on the most influential journals in venture capital research.

In this study, the bibliometric review aims to extend the literature by globally analysing venture capital publications in different Web of Science (WOS) categories. Our bibliometric analysis covers 1,840 papers and focuses on the quality and quantity of venture capital research over the last two decades using the VOSviewer software. The review aims to cover most of the perspectives in the bibliometric analysis to give an overview of this research topic and its trends. Therefore, co-authorship, co-citation, and co-occurrence are included in the analysis, with maps indicating their cooperation networks and influence. Available bibliometric information was used as a basis for decision-making and performance assessment of funding agencies and research and recruitment institutions (Butler, 2003; Abramo et al., 2009; Schneider, 2009; Hicks et al., 2015; Moher et al., 2018). Hence, the main contribution of this review is to support decision-making in a venture capital research management context.

In addition, the aim is to provide clarification for future researchers or evaluators, including research patterns, influential authors and publications, core journals, countries, and institutions. The main influential research clusters and the overall development of the research topics on venture capital, as well as citations and cocitation analysis, open access vs. non-open access policy are addressed. This study also provides both theoretical and practical insights to support and guide research, particularly on emerging financial markets. The paper is organised as follows: first, the details of the data collection and the methods used in the analysis are presented, then the conclusions drawn from the bibliometric data and network maps are summarised, and the main conclusions are discussed. Finally, the limitations and implications of the review are highlighted.

\section{DATA AND METHODS}

In any empirical study, reliable data is identified as the pivotal core to valuable research. Therefore, most bibliometric studies emphatically use archival records to collect raw data (Milojević, 2014). To this end, this paper focuses on the extraction of data from bibliographic records, taking advantage of common indexes. The Scientific Citation Index (SCI), Social Science Citation Index (SSCI), and Arts and Humanities Citation Index (AHCI) (Karaulova et al., 2016; Liu et al., 2017; 
van Nunen et al., 2018) were used to collect the necessary information from the WOS core collection database on 31 January 2019. The keyword "venture capital" was used as a search topic from 2000 to 2018. This topic search means that the term "venture capital" is identified in the title, abstract, and/or keywords of the publications. Table 1 provides an overview of the data and methods used in this study. It is important to note that changing the date of data acquisition can change the results, and this is due to fact that the WOS is continuously updated - also retrospectively - which may result in minor changes over time (Liu et al., 2013; van Nunen et al., 2018).

In this study a total of 1,840 publications on venture capital were considered. All available publications types $(\mathrm{n}=11)$ and in different categories $(\mathrm{n}=25)$ were included in the analysis. The database contains complete records and cited references for each publication, such as author name(s), publication title(s), publication type(s), author affiliation(s), subject category(ies), publication citation(s), publication abstract, publication reference(s), and relevant details. England, Scotland, Wales, and North Ireland were grouped within the UK group. Although with the high quality of the WOS Core Collection database, the problem of missing data exists. Table 2 shows the missing data in the WOS database. This indicates that the publications with missing data in a field were discarded in each field-related analysis (e.g., publications with missing data in the author's field were discarded in the author and cooperation analysis).

Table 2 indicates that 197 publications (10.71\%) did not contain data in the field of abstract, 184 publications (10\%) in the field of reference(s), 184 publications $(10 \%)$ in the field of author affiliation(s) (includes countries and organisations), 33 publications $(1.79 \%)$ in the field of authors, and 1 publication $(0.05 \%)$ in the field of category(ies). This data did not systematically exist in some publications because of their type. Indeed, several researchers have indicated that ignoring missing data in the WOS database may lead to inaccurate results (Franceschini et al., 2016; Liu et al., 2018; Zhu et al., 2019). To this end, two free software programs, Microsoft Excel and VOSviewer (version 1.6.11) (www.vosviewer. com), were used to analyse and display data to complete the analysis of this study. Database in tab-delimited format (Win) was inserted in Microsoft Excel for further cleaning, and to create tables and curves. VOSviewer was used to build and display bibliometric maps (van Eck \& Waltman, 2010). Based on the bibliographic data, the co-authorship and co-citation maps were created. Authors, organisations, and countries were used as the unit of analysis in co-authorship, and cited references were used as the unit of analysis in co-citation. Also, a map of co-occurrence terms based on text data was created. 


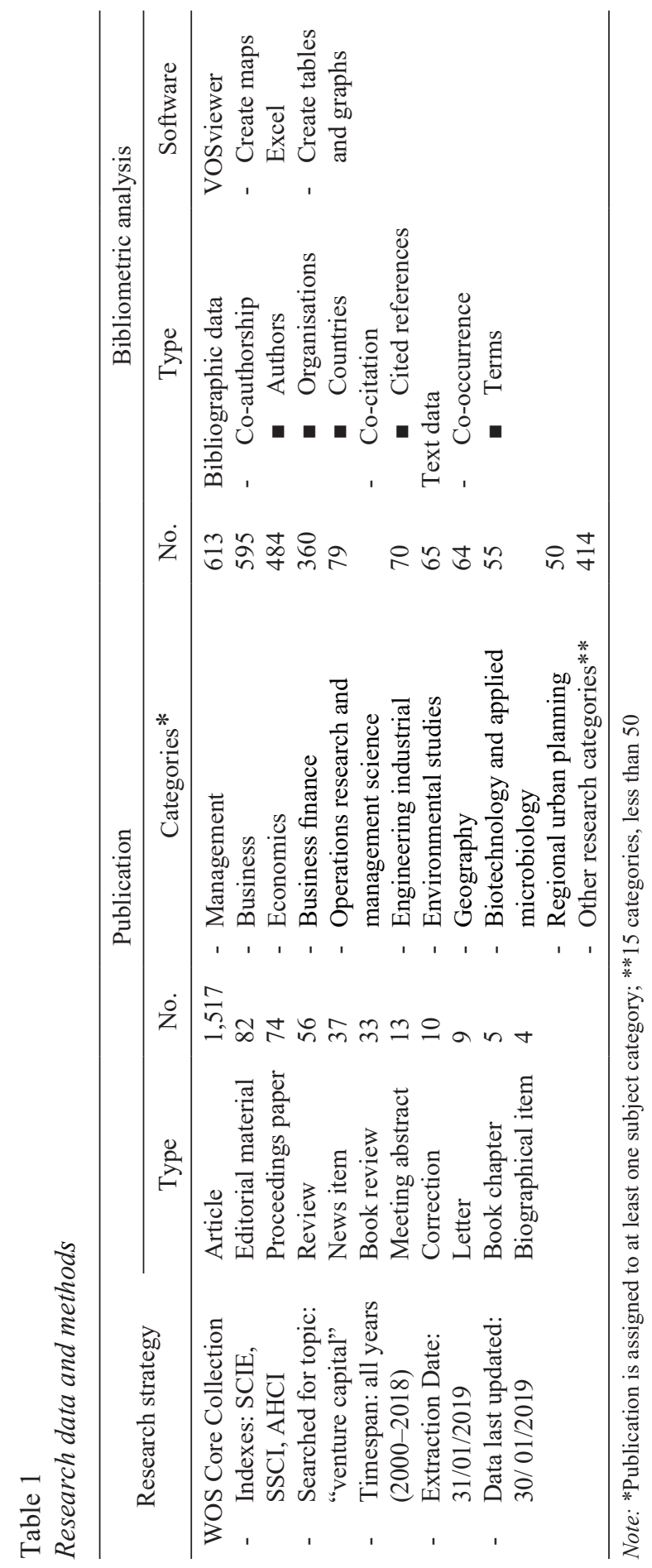




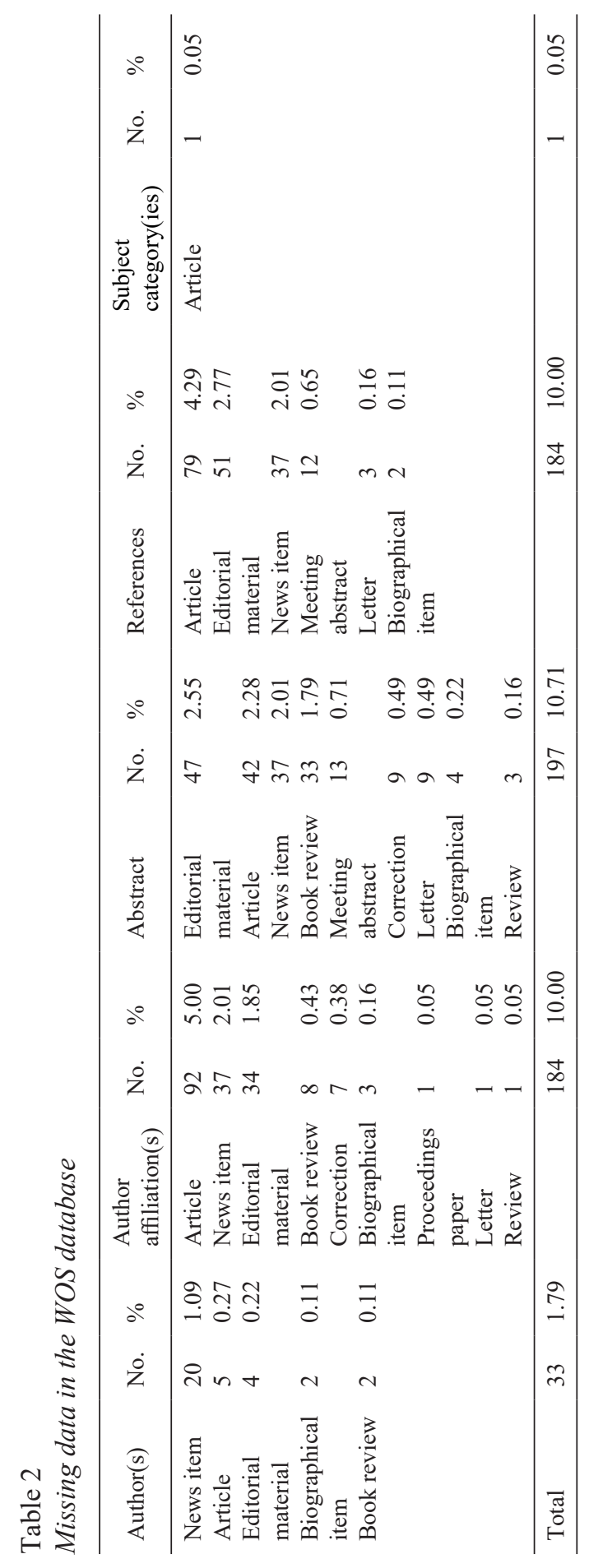




\section{RESULTS AND DISCUSSION}

This section presents and discusses the results obtained. It is important to note that the data collected from the WOS records for the period 2000-2018 reflects the search results at the time of the evaluation.

\section{Publication Output and Growth Trend}

From 2000 to 2018, and over the past two decades, the number of peer-reviewed venture capital publications has considerably increased (Figure 1), which represents the evolution of venture capital research publications. According to the WOS records, an increasing trend in the number of publications can be observed. The average number of papers published per year in the venture capital field is 97 publications, with the highest number recorded in 2014 and 2016, with 147 and 154 publications, respectively.

In general, the venture capital research field has received more attention in the last 10 years. The cumulative number of publications in this area over the last two decades has reached a total of 1,840 publications, which represents more than $65 \%$ (1,201 publications) published over the last 10 years (Figure 1). The paper by Cornelius and Persson (2006) allowed to compare the evolution of the number of publications in the venture capital field before 2005 and over the last decade, which translates into a steadily increasing rate of venture capital research.

The trendline of the cumulative number of publications between 2000 and 2018 was studied in more detail and plotted in Figure 1. In the case of exponential growth, a significant correlation was observed between the cumulative number of venture capital publications and the period 2000-2018, with a coefficient of determination $\left(\mathrm{R}^{2}=0.81\right)$. The trendline equation provides insight into the future evolution of the venture capital research topic, taking into consideration that the WOS can be updated by adding other sources, i.e., by indexing new journals. 


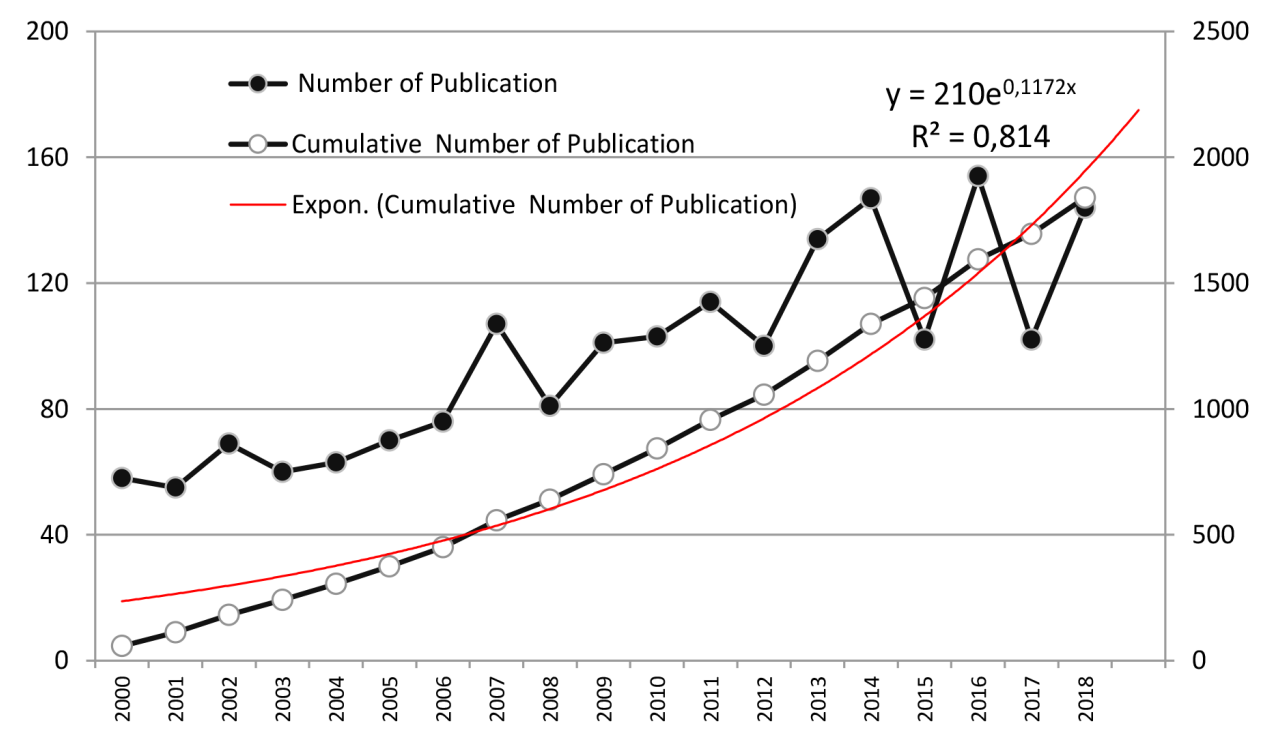

Figure 1. Number of venture capital publications and cumulative number of venture capital publications per year

\section{Authors and Their Cooperation}

According to the WOS records, a total of 1,840 publications were published by 2,607 different authors, with the exception of 33 that were not identified by name (anonymous; see Table 2). Under these conditions and to limit bias, authors with similar names or using different names in their publications were identified and merged (e.g., Cumming, D. and Cumming, D.J.). Consequently, the average number of authors per publication was 1.41 . In other words, $30.65 \%$ $(\mathrm{n}=564 / 1,840)$ of the publications had a single author, compared to $34.4 \%$ $(n=633 / 1,840)$ of the publications had two authors. Whereas, $23.8 \%(n=438 / 1,840)$ of the publications had three authors, and $9.35 \%(\mathrm{n}=172 / 1,840)$ had more than three authors (with a maximum of 12 authors). Therefore, it can be noted that there is a highly collaborative work element among researchers in the field of venture capital research with multi-authored publications accounting for approximately $68 \%$ of all titles. A considerable number of co-authored publications indicates tremendous potential for future collaboration (van Nunen et al., 2018).

Table 3 lists the 10 most productive authors publishing in the venture capital domain. The ranking is based on the author's total number of publications, as shown, Cumming ranking first with 52 publications, followed by Wright with 34 publications. In contrast, the productivity of the other authors ranges between 18 and 13 publications. According to the number of citations and the number of 
citations per publication, Lerner is the most cited author in venture capital research (average citation per publication $=128.5$ ) despite his 18 publications ranking him after Cumming and Wright. Lockett $(\mathrm{n}=68.47)$ and Wright $(\mathrm{n}=54.29)$ are also considered among the most cited authors.

Table 3

Top 10 of most productive authors publishing on venture capital

\begin{tabular}{lllcccc}
\hline No.* & Author name & $\begin{array}{l}\text { Country } \\
\text { of author }\end{array}$ & $\begin{array}{c}\text { Number of } \\
\text { publications }\end{array}$ & Citations & $\begin{array}{c}\text { Average } \\
\text { citations per } \\
\text { publication }\end{array}$ & $\begin{array}{c}\text { Number of } \\
\text { publications as } \\
\text { first author }\end{array}$ \\
\hline 1 & Cumming, D.J & USA & 52 & 2,153 & 41.40 & 46 \\
2 & Wright, M. & UK & 34 & 1,846 & 54.29 & 5 \\
3 & Lerner, J. & USA & 18 & 2,313 & 128.50 & 10 \\
4 & Manigart, S. & Belgium & 18 & 551 & 30.61 & 3 \\
4 & Schwienbacher, A. & France & 18 & 409 & 22.72 & 3 \\
6 & Mason, C.M. & UK & 16 & 838 & 52.38 & 12 \\
7 & Lockett, A. & UK & 15 & 1,027 & 68.47 & 4 \\
7 & Haula, M.V.J. & Finland & 15 & 629 & 41.93 & 3 \\
8 & Johan, S.A.B. & Canada & 13 & 266 & 20.46 & 7 \\
\hline
\end{tabular}

Note: *Equally productive authors have the same ranking number

Co-authorship illustrates the number of publications of the authors and how they are interconnected. The co-authorship network in venture capital research was analysed with VOSviewer and is presented in Figure 2. The size of the circles indicates the number of publications, and the distance between the circles in the viewer approximates the relationship or similarity. The thickness of the link between authors also indicates the strength of co-authorship (van Eck \& Waltman, 2014). The network includes only 204 authors in total in 16 clusters. No cluster includes authors who have published less than two papers on the topic or have not connected with other authors in the network.

The significance of Cumming and Wright can be appreciated and represented in two main clusters. The map (Figure 2) indicates that Johan and Schwienbacher are in the same cluster as Cumming, while Lockett and Manigart are in the same cluster as Wright. Although Lerner, Mason, and Harrison have a significant number of publications as first author (10,12, and 7, respectively), these authors are not displayed on the cooperation network because of their low collaborative work. In addition to the two clusters of top-ranked authors, other main clusters 
of authors can be distinguished on the cooperation network formed by Maula, Colombo, Mohamed, Sorenson, and Kaplan. Other researchers are linked to one of these prominent researchers.

Figure 3 shows a comparison between two main authors' clusters overtime, the Cumming and Wright clusters. The results indicate that Cumming's cluster is the largest cluster with 31 items compared to 21 items for Wright's cluster. However, Wright has the greatest co-authorship links among all other authors with the highest total link strength $(n=63)$ across all 34 publications. It is important to note that the total link strength represents the total strength of the author's co-authorship links with all others, while links represent the number of the author's links with others, and both are not equal to the number of publications (van Eck \& Waltman, 2013; Anwar et al., 2019). Wright has 24 links; he has 13 publications with Lockett, most of them published around 2010, while Manigart is the second co-author in terms of number of publications with Wright (8), most of which were published around 2012. Cumming ranks second in terms of the co-authorship with 56 total link strength in its 52 papers. He has 26 links; eight of them were published with Johan around 2013, six with Schwienbacher around 2012 and six with Fleming around 2008. Cumming is the most productive author, and his publications are the most recent and published with a considerable number of authors.

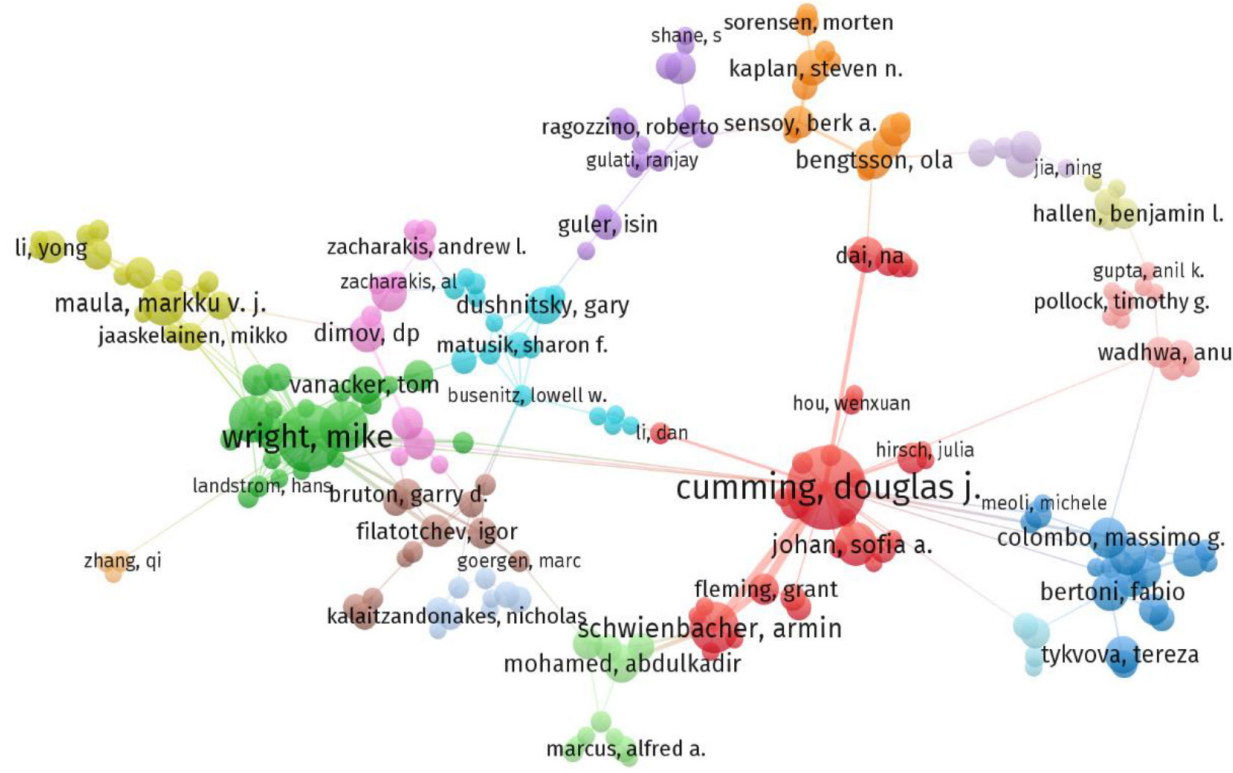

Figure 2. Authors cooperation in venture capital research 

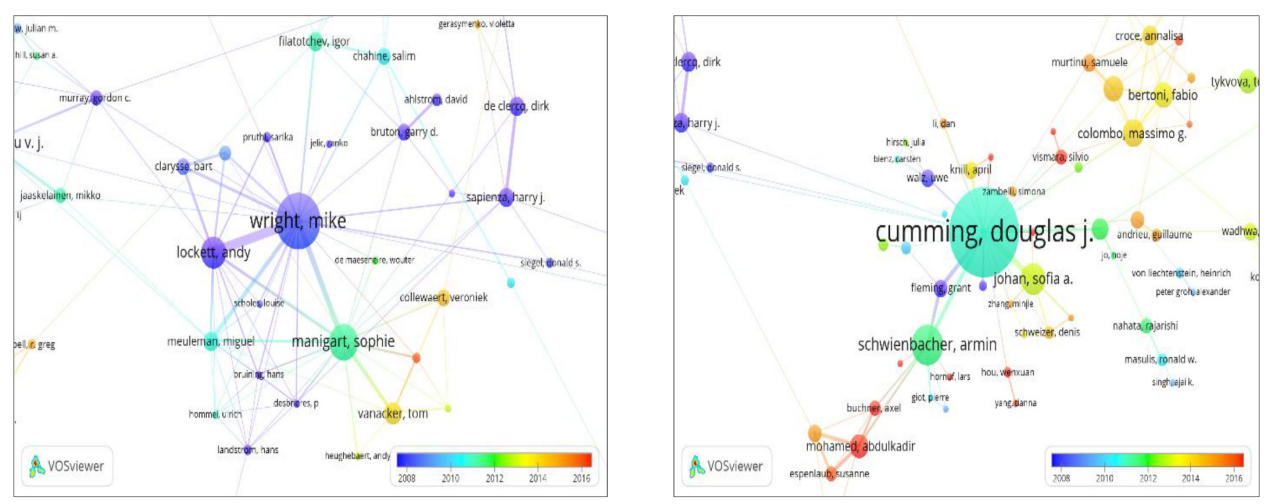

Figure 3. Main clusters analysis

\section{Journals Publishing on Venture Capital}

At the time of this evaluation, venture capital publications were published in 518 (99.23\%) source titles (journals and magazines) and four (0.77\%) book series titles. Among the source titles, there was a small contribution from 438 journals (84.55\%), where they published less than five publications. More than half of the journals $(57.52 \%)$ published only one publication, and 85 journals $(16.4 \%)$ published only two publications; 49 journals (9.45\%) published 10 publications or more on venture capital. Table 4 details the 10 most active journals publishing on venture capital. These journals represent $22.6 \%(416 / 1,840)$ of all publications and $36.66 \%(17,620 / 48,063)$ of total citations. Journal of Business Venturing is the most active $(\mathrm{n}=92)$ and the most cited $(\mathrm{n}=5,746)$ journal, followed by Small Business Economic and Journal of Corporate Finance.

The results show that the majority of contributions in the most active journals are published in the business and management categories, as well as in the economics, finance, accounting and finance, engineering, and operations research and management science categories. When considering all source titles (Table 1), the management category is the most frequent (with 613 publications), followed by business (with 595 publications). In addition to those mentioned previously, venture capital research results from many other categories such as biotechnology and applied microbiology (e.g., in the journal Nature Biotechnology), chemistry multidisciplinary (e.g., in the journal Chemical and Engineering News), environmental studies (e.g., in the journal European Planning Studies), and political science (e.g., in the journal Technological Forecasting and Social Change). 
Table 4

Top 10 of most active journals publishing on venture capital

\begin{tabular}{|c|c|c|c|c|c|}
\hline No.* & Journal title & $\begin{array}{c}\text { No. of } \\
\text { publications }\end{array}$ & $\begin{array}{l}\text { No. of } \\
\text { citations }\end{array}$ & $\begin{array}{l}\text { Impact } \\
\text { Factor** }\end{array}$ & Subject category \\
\hline 1 & $\begin{array}{l}\text { Journal of Business } \\
\text { Venturing }\end{array}$ & 92 & 5,746 & 6 & $\begin{array}{l}\text { Business, economics } \\
\text { and business }\end{array}$ \\
\hline 2 & $\begin{array}{l}\text { Small Business } \\
\text { Economics }\end{array}$ & 65 & 1,361 & 2.852 & $\begin{array}{l}\text { Business, economics, } \\
\text { management }\end{array}$ \\
\hline 3 & $\begin{array}{l}\text { Journal of } \\
\text { Corporate Finance }\end{array}$ & 47 & 1,280 & 2.215 & $\begin{array}{l}\text { Economics, business, } \\
\text { finance }\end{array}$ \\
\hline 4 & Research Policy & 39 & 2,484 & 4.661 & $\begin{array}{l}\text { Management, social } \\
\text { sciences, general }\end{array}$ \\
\hline 5 & $\begin{array}{l}\text { Journal of Financial } \\
\text { Economics }\end{array}$ & 37 & 2,374 & 5.162 & $\begin{array}{l}\text { Business, finance, } \\
\text { accounting and finance, } \\
\text { economics }\end{array}$ \\
\hline 6 & $\begin{array}{l}\text { Entrepreneurship } \\
\text { Theory and } \\
\text { Practice }\end{array}$ & 34 & 1,201 & 5.321 & $\begin{array}{l}\text { Economics and } \\
\text { business, business, } \\
\text { economics }\end{array}$ \\
\hline 7 & $\begin{array}{l}\text { Strategic } \\
\text { Management } \\
\text { Journal }\end{array}$ & 28 & 2,362 & 5.482 & $\begin{array}{l}\text { Management } \\
\text { and organisation, } \\
\text { management, business }\end{array}$ \\
\hline 8 & $\begin{array}{l}\text { International } \\
\text { Journal of } \\
\text { Technology } \\
\text { Management }\end{array}$ & 26 & 196 & 0.869 & $\begin{array}{l}\text { Engineering, } \\
\text { multidisciplinary; } \\
\text { management, } \\
\text { operations research and } \\
\text { management science }\end{array}$ \\
\hline 9 & $\begin{array}{l}\text { Journal of Banking } \\
\text { and Finance }\end{array}$ & 24 & 614 & 1.931 & $\begin{array}{l}\text { Business, finance, } \\
\text { economics, accounting } \\
\text { and finance }\end{array}$ \\
\hline 10 & $\begin{array}{l}\text { Strategic } \\
\text { Entrepreneurship } \\
\text { Journal }\end{array}$ & 24 & 404 & 3.488 & $\begin{array}{l}\text { Management, business, } \\
\text { economics and business }\end{array}$ \\
\hline
\end{tabular}

Note: *Equally active journals have the same ranking number; **Impact Factors were retrieved from the 2018 Journal Citation Reports

\section{Languages, Countries and Institutional Distribution and Cooperation}

\section{Languages and countries of publications}

Based on the evaluation, venture capital publications are published in eight languages, most of them $(98.64 \% ; n=1,815 / 1,840)$ being published in English. There are publications in German $(n=12)$, Russian $(n=5)$, French $(n=3)$, 
Spanish $(\mathrm{n}=2)$, Polish $(\mathrm{n}=1)$, Slovak $(\mathrm{n}=1)$, and Czech $(\mathrm{n}=1)$. The English language dominates the research on venture capital topic in the WOS database (see also Waltman, 2016; Mongeon \& Paul-Hus, 2016; Martín-Martín et al., 2018). Therefore, the language is a limiting factor in the global research conversation on venture capital. According to Li and Flowerdew (2007), Flowerdew (2008), Cargill and O'Connor (2006), and McKinley and Rose (2018), the huge impetus for researchers to write in English is actually to publish in international journals, even if they use it as an additional language. The impact of language is crucial for the multilingual scholars as they engage untapped or unknown resources (Flowerdew, 2001; Curry \& Lillis, 2004; Uzuner, 2008; Mu, 2020), especially in the non-native English-speaking countries where large emerging markets are shaping and forming their venture capital industry development (e.g., China, Germany, or Japan).

Given that these publications are submitted from 66 countries, they were determined based on the authors' affiliations. Therefore, the same publication can originate from more than one country. Figure 4 shows the USA accounts for the largest number of publications $(n=773)$, followed by the UK $(n=266)$, Canada $(n=151)$, Germany $(n=132)$, and China $(n=122)$. It is worth noting that the top 10 countries are all developed countries. The majority of publications $(91.62 \%$; $\mathrm{n}=2,100 / 2,292$ ) were published in these countries, while noting a lower percentage for developing and in transition countries $(7,98 \% ; n=183 / 2,292),(0,13 \%$; $\mathrm{n}=3 / 2,292$ ), respectively. Even so, the underlying causes of the high interest in venture capital research may be difficult to identify, but certain political (Anderson et al., 2017; Wang et al., 2018), social, and economic factors (Bjerke \& Hultman, 2004; Landström, 2007; Landstrom, 2007) may have a potential effect. Moreover, we can observe the causal relationship amongst scientific research, knowledge, and economic development (Yang et al., 2013; Bhargava, 2016).

Based on the titles of these publications, occurrence analysis was used to find the most occurring countries and territories. These countries and territories were mentioned as empirical, evidence, or case studies areas in venture capital publications. The results show that there are 48 clearly defined empirical or evidence areas and they occur 395 times (some publications have more than one area). They represent: 395, 37.97\% $(n=150)$ in Europe, $31.64 \%(n=125)$ in Asia, $22.02 \%(n=87)$ in North America, 4.88\% $(n=20)$ in Africa, $1.71 \%(n=1)$ in Oceania, and $1.46 \%(n=6)$ in Latin America. 


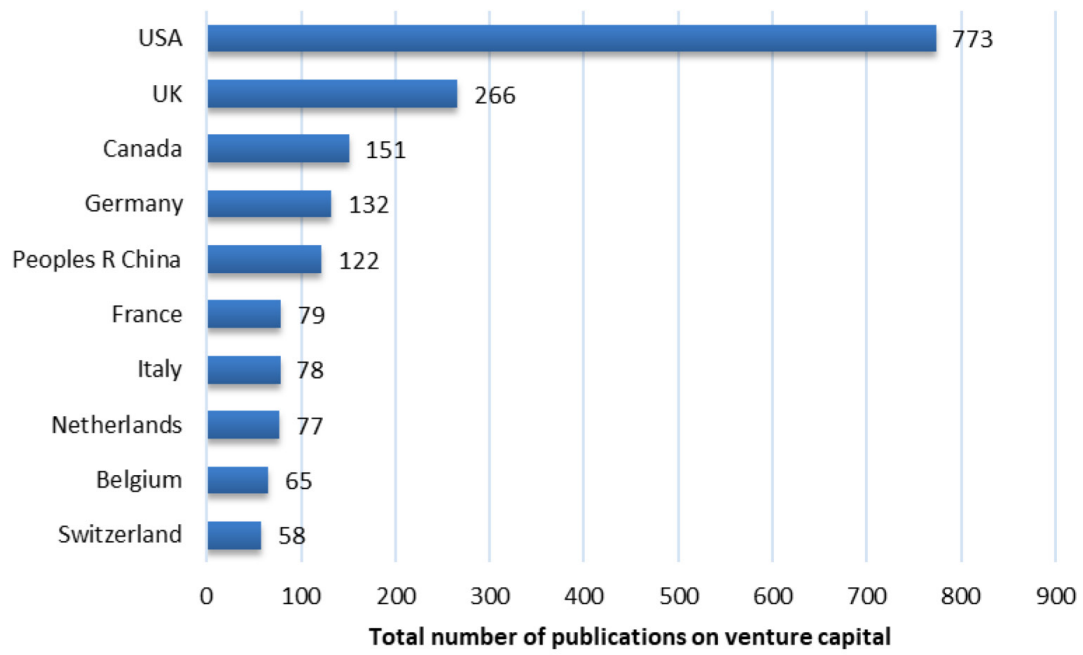

Figure 4. Top 10 of most productive countries publishing on venture capital based on author affiliation

In terms of countries as areas of studies, USA $(n=73)$ is the most occurred, followed by China $(n=65)$ and Germany $(n=26)$. On the other hand, given the average publications growth rate in these countries during the last five years, China (with $21 \%$ ) surpasses the USA (with $9.8 \%$ ). This means that China will clearly emerge in the near future as a more inspiring country for venture capital research. The Asian continent draws attention to the need for further discussion on countries. Table 5 summarises the state of venture capital research in the Asian territory/ countries. A few countries have participated in the case study on venture capital in Asia, where China, Japan, South Korea, and India are included in most of the publications. These countries have specifically tested venture capital-related topics such as entrepreneurship (e.g., Suzuki et al., 2002; Dai et al., 2012; Scheela et al., 2015), networks (e.g, Batjargal \& Liu, 2004; Lehrer \& Asakawa, 2004; Bruton et al., 2009; Scheela et al., 2015), institutional theory (e.g., Bruton \& Ahlstrom, 2003; Bruton et al., 2004; Bruton et al., 2009), emerging and transition economies (e.g., White et al., 2005; Batjargal, 2007; Bruton et al., 2009; Scheela et al., 2015), R\&D and innovation (e.g., Lynskey, 2004; Wang et al., 2005), and contracts and ownership structure (e.g., Yoshikawa et al., 2004; Mayer et al., 2005). However, a more in-depth analysis could usefully explore the rationale and causes of the influence of countries, as place of author affiliation or as areas of study, on venture capital publications, taking into account the different institutional contexts. 
Table 5

Venture capital research on Asian territory/countries

\begin{tabular}{|c|c|c|c|c|}
\hline $\begin{array}{l}\text { Asian } \\
\text { territory }\end{array}$ & $\begin{array}{l}\text { TN of } \\
\text { publications }\end{array}$ & $\begin{array}{l}\text { Total } \\
\text { C }\end{array}$ & Publication(s)* & Main topic related to $\mathrm{VC}$ \\
\hline Asia & 10 & 199 & $\begin{array}{l}\text { Bruton et al. (2009); Dai } \\
\text { et al. (2012); Bruton et al. } \\
\text { (2004); Scheela et al. (2015); } \\
\text { Zhang et al. (2016) }\end{array}$ & $\begin{array}{l}\text { Institutional theory; } \\
\text { syndication; emerging } \\
\text { economies; ethnic enclave; } \\
\text { entrepreneurship; social } \\
\text { network }\end{array}$ \\
\hline China & 65 & 1,074 & $\begin{array}{l}\text { Bruton and Ahlstrom (2003); } \\
\text { Batjargal and Liu (2004); } \\
\text { Batjargal (2007); White et al. } \\
\text { (2005); Wang et al. (2005) }\end{array}$ & $\begin{array}{l}\text { Institutional theory; social } \\
\text { networks; entrepreneurship; } \\
\text { transition economy; R\&D }\end{array}$ \\
\hline Japan & 16 & 260 & $\begin{array}{l}\text { Mayer et al. (2005); Lynskey } \\
\text { (2004); Suzuki et al. (2002); } \\
\text { Lehrer and Asakawa (2004); } \\
\text { Yoshikawa et al. (2004) }\end{array}$ & $\begin{array}{l}\text { Contracts; networks; R\&D; } \\
\text { entrepreneurship; ownership } \\
\text { structure }\end{array}$ \\
\hline India & 11 & 179 & $\begin{array}{l}\text { Dossani and Kenney (2002); } \\
\text { Wright et al. (2002); Sonne } \\
\text { (2012); Mani (2004); Bhatt } \\
\text { and Ahmad (2017) }\end{array}$ & $\begin{array}{l}\text { Entrepreneurship; inclusive } \\
\text { finance and innovation; } \\
\text { social impact investment; } \\
\text { internationalisation }\end{array}$ \\
\hline $\begin{array}{l}\text { South } \\
\text { Korea }\end{array}$ & 10 & 22 & $\begin{array}{l}\text { Cho and Lee (2013); Lim } \\
\text { and Kim (2015); Kim and } \\
\text { Heshmati (2010); Jung et al. } \\
\text { (2017); Song et al. (2014) }\end{array}$ & $\begin{array}{l}\text { IPO; technology; } \\
\text { entrepreneurial; } \\
\text { developmental state }\end{array}$ \\
\hline Taiwan & 4 & 156 & $\begin{array}{l}\text { Kung and Wen (2007); } \\
\text { Saxenian and Li (2003); } \\
\text { Tang and Chyi (2008); Wang } \\
\text { and Tsai (2005) }\end{array}$ & $\begin{array}{l}\text { Grey system; investment } \\
\text { network; R\&D; decision- } \\
\text { making }\end{array}$ \\
\hline Singapore & 3 & 60 & $\begin{array}{l}\text { Wang and Ang (2004); } \\
\text { Lu and Hwang (2010); } \\
\text { Wonglimpiyarat (2013) }\end{array}$ & $\begin{array}{l}\text { Liability of foreignness; } \\
\text { deals; national innovation } \\
\text { system }\end{array}$ \\
\hline Malaysia & 2 & 23 & $\begin{array}{l}\text { Indergaard (2003); Harrison } \\
\text { et al. (2018) }\end{array}$ & Institutional theory \\
\hline Thailand & 1 & 6 & Wonglimpiyarat (2013) & National innovation system \\
\hline Vietnam & 1 & 4 & Klingler-Vidra (2014) & $\begin{array}{l}\text { Industrial policy; } \\
\text { international organisations }\end{array}$ \\
\hline Pakistan & 1 & 8 & Arshad et al. (2018) & $\begin{array}{l}\text { Renewable energy } \\
\text { investment }\end{array}$ \\
\hline Iran & 1 & 0 & Malekdar (2012) & $\begin{array}{l}\text { Science and technology } \\
\text { parks }\end{array}$ \\
\hline
\end{tabular}

Note: * The publications arranged in citations order from the most to the less. We focused on the top 5, if they're more than $5 . \mathrm{TN}=$ total number; $\mathrm{C}=$ citation; $\mathrm{VC}=$ venture capital 
Figure 5 shows the co-authorship between countries, where network countries have published more than 10 publications on the topic. The network consists of circles and edges, while the circles represent the countries, and the distance between them indicates relatedness or similarity; the edges represent the cooperation between these countries. The visualisation of the network indicates three clusters, each cluster includes countries that have a relatively strong relation. Only the countries with the greatest total link strength are selected. The USA is a pivotal country in the red cluster, and it has three other major contributors: Canada, China, and Australia. The USA has cooperated frequently with Canada, the UK, China, Switzerland, and Germany with 49, 46, 39, 15, and 12 cooperative publications $(\mathrm{CPs})$, respectively. The UK is a pivotal country in the green cluster, and it has cooperated frequently with six other major contributors: Germany $(\mathrm{CPs}=21)$, Belgium ( $\mathrm{CPs}=21)$, the Netherlands (CPs $=14)$, France (CPs $=12)$, Italy (CPs $=8)$, and Spain $(\mathrm{CPs}=5)$. Switzerland is a pivotal country in a small blue cluster with Finland ( $\mathrm{CPs}=5)$, Denmark $(\mathrm{CPs}=4)$, Austria $(\mathrm{CPs}=3)$, and Sweden (CPs $=1$ ) as major contributors.

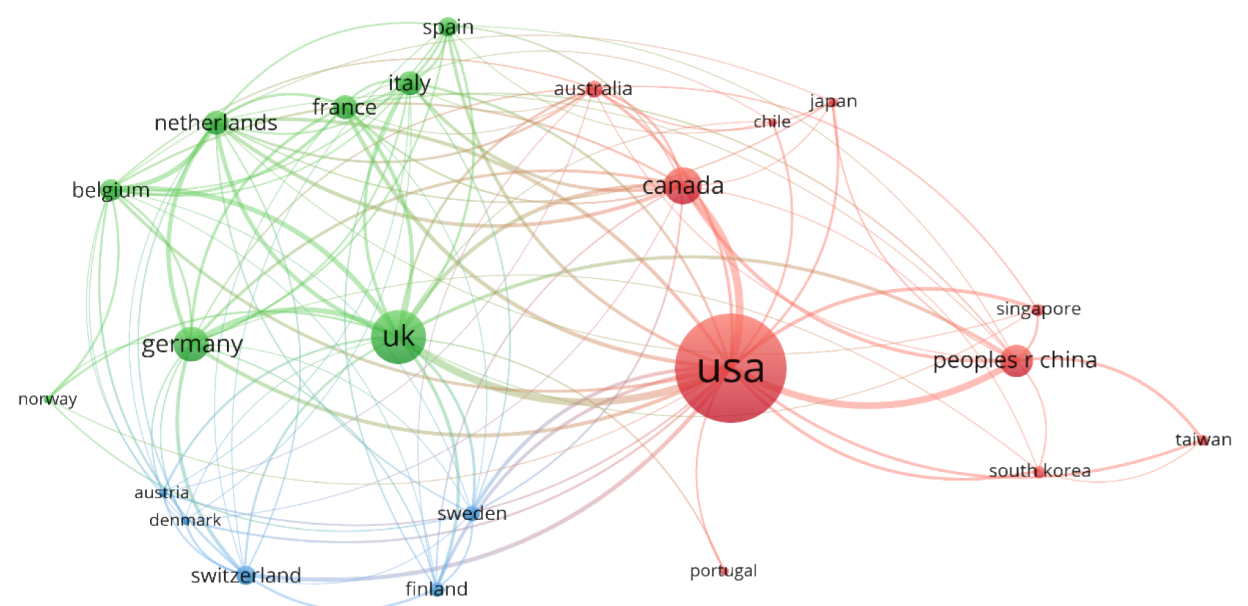

Figure 5. Cooperation network between countries in venture capital research

In addition to the previous analysis on Asian territory/countries, China has frequently cooperated with Taiwan $(\mathrm{CPs}=8)$, Singapore $(\mathrm{CPs}=5)$, South Korea $(\mathrm{CPs}=2)$, and Japan $(\mathrm{CPs}=2)$. Moreover, with a total of $84 \mathrm{CPs}$, China has cooperated with Asian countries in only 18 of them. As noted in other scientific research fields, the collaborative countries are, in general, geographically correlated and centered around the most productive countries (Zheng et al., 2016; van Nunen et al., 2018). As a result, the increase in China's venture capital publications is likely to broaden the Asian research network connected to and centered on China. 
Talking into consideration the average publication years, it can be noticed that the most recent publications were by China (around 2014), compared to Canada (around 2011), the USA, the UK, and Germany (around 2010).

\section{Organisations}

Considering the participation of organisations, it reached a total of 1,280 different research organisations that participated in 1,656 publications. One should keep in mind the neglect of publications that do not contain the organisations' data (Table 2). Most organisations (65.39\%) have a very low participation in venture capital research, as evidenced by participated in one publication only, while 14 organisations $(1 \%)$ produced 20 or more publications. Figure 6 shows the 10 most productive organisations, and as can be seen, the USA is represented by five organisations, including Harvard University, which is the most productive $(\mathrm{n}=59)$ organisation in terms of venture capital. It is therefore interesting to determine the reasons that may have led organisations to pay more attention to venture capital research. These reasons are of great importance, but their inclusion in this discussion must be accompanied by additional information that the WOS database does not have, such as organisations categories (i.e., academic, private, or governmental), major policy in research, investment and funding, and the availability of venture capital in the organisation area.

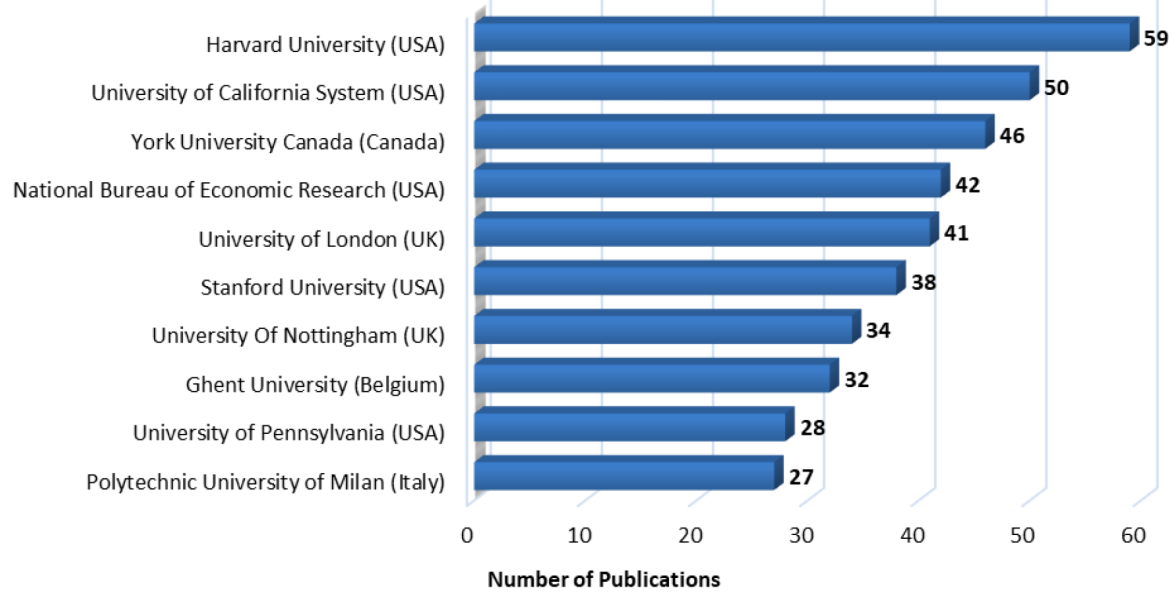

Figure 6. Top 10 of most productive organisations publishing on venture capital 


\section{Cited analysis}

This analysis indicates the citation number of the publications (each publication) as a reference (Li \& Hale, 2015; van Nunen et al., 2018). The results indicate that at the time of the evaluation that the venture capital publications were cited 48,063 times as a reference in WOS publications, by an average of $26.12(\mathrm{n}=48,063 / 1,840)$, while one-fifth $(\mathrm{n}=21.14 \%)$ of publications were not used as a reference. The majority (93.86\%) of publications were cited 100 times or less, and more than half $(59.35 \%)$ were cited 10 times or less, while $38.20 \%$ of publications were cited from one time to ten times. Figure 7 shows that open access publications (OAPs) and non-open access publications (non-OAPs) both contribute to the number of publications and citations. OAPs account for about one tenth $(9.51 \%=175 / 1,840)$ of all publications and $14.09 \%(\mathrm{n}=6,772 / 48,063)$ of total citations, while the average of OAPs citations per publication is $38.7(\mathrm{n}=6,772 / 175)$. Therefore, it is clear that the OAPs contribution to citations exceeds their contribution to the number of publications in most years, in contrast to the non-OAPs. As a result, OAPs increase the citation rate of venture capital publications.

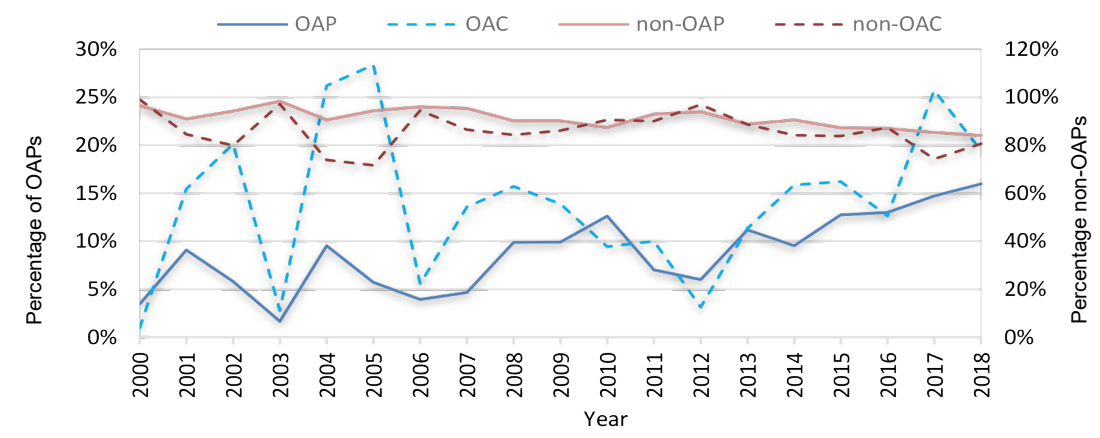

Figure 7. OAPs and non-OAPs contribution in the number of publications and citations

Powell et al. (2005) and Lee et al. (2001) have the most cited publications. Table 6 indicates that the "Network dynamics and field evolution: The growth of interorganizational collaboration in the life sciences" and "Internal capabilities, external networks, and performance: A study on technology-based ventures" publications were cited 789 times. Considering the average citation, the publication by Powell et al. (2005) was cited 56.36 times per year. This is the highest citation average, compared to the most frequently cited venture capital publications, which represent $0.54 \%(n=10 / 1,840)$ of the publications and $12.77 \%(n=6,140 / 48,063)$ of the citations. The time span of these most cited publications was from 2000 to 2005. According to citation behaviour studies, the probability of being cited depends on many factors such as time (Case \& Higgins, 2000; Bornmann \& 
Daniel, 2008), the prestige, language and availability of the publishing journal (van Leeuwen et al., 2001; van Raan, 2005; Bornmann et al., 2008; Zhu et al., 2015), and social networks that exist among authors (White, 2001; Stokols et al., 2008). Therefore, researchers should use citation analysis, taking these factors into account.

With respect to the main topic, the contribution of venture capital to entrepreneurship covers four out of ten publications. The other publications address topics related to the relationship between venture capital and capitalisation, collaboration, or innovation. The results show that the American Journal of Sociology was the journal that published the most cited publications, and it is the most representative with three times as many publications. Linking the number of citations to the publishing policy (OAP/non-OAP), only two publications have an OAP policy. OAP increases citation rates in venture capital research, where citation impact factors are obtained by comparing the citation numbers for each OAP and nonOAP appearing in the same (non-OAP) journals (Harnad \& Brody, 2004). 


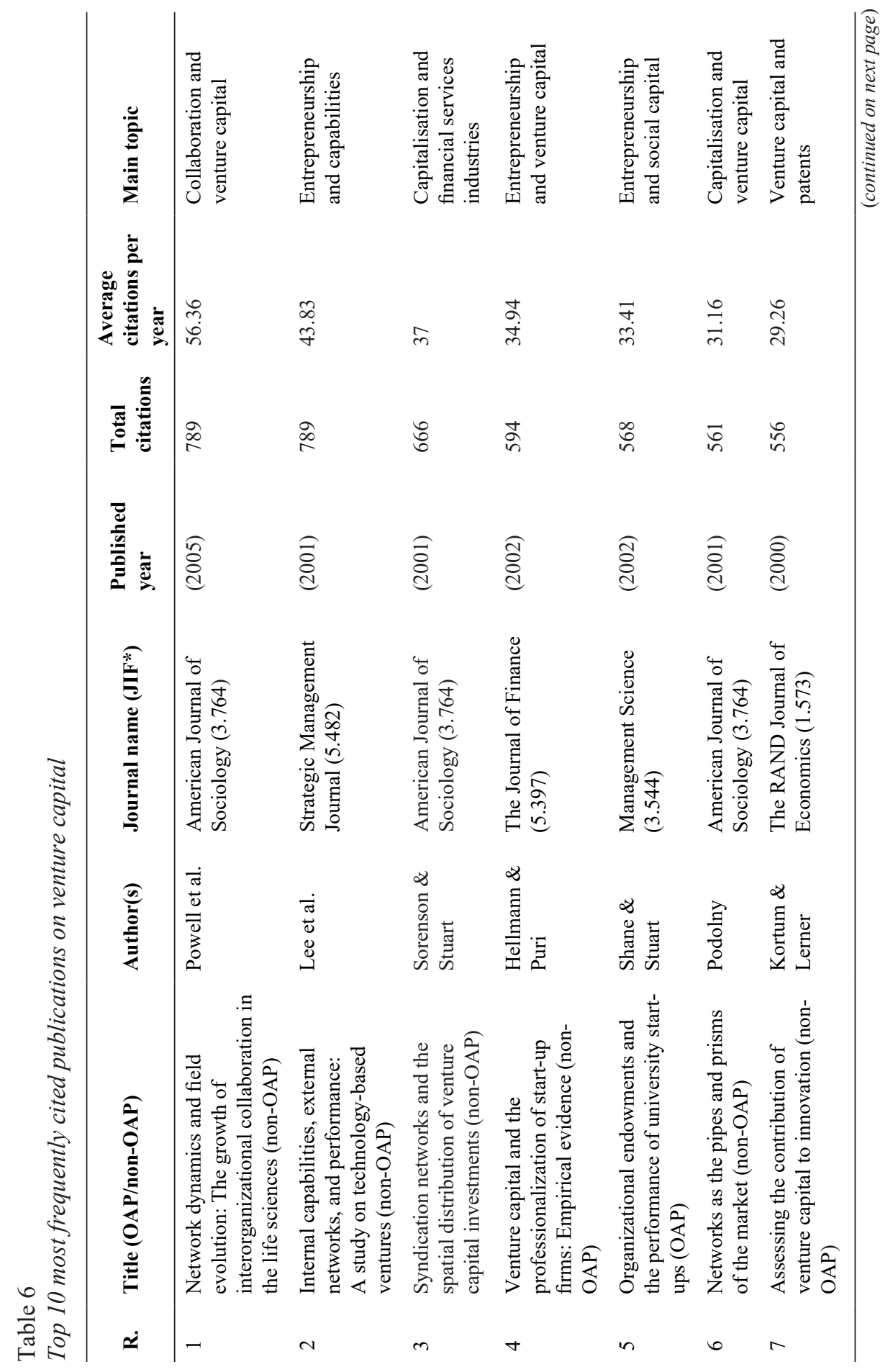




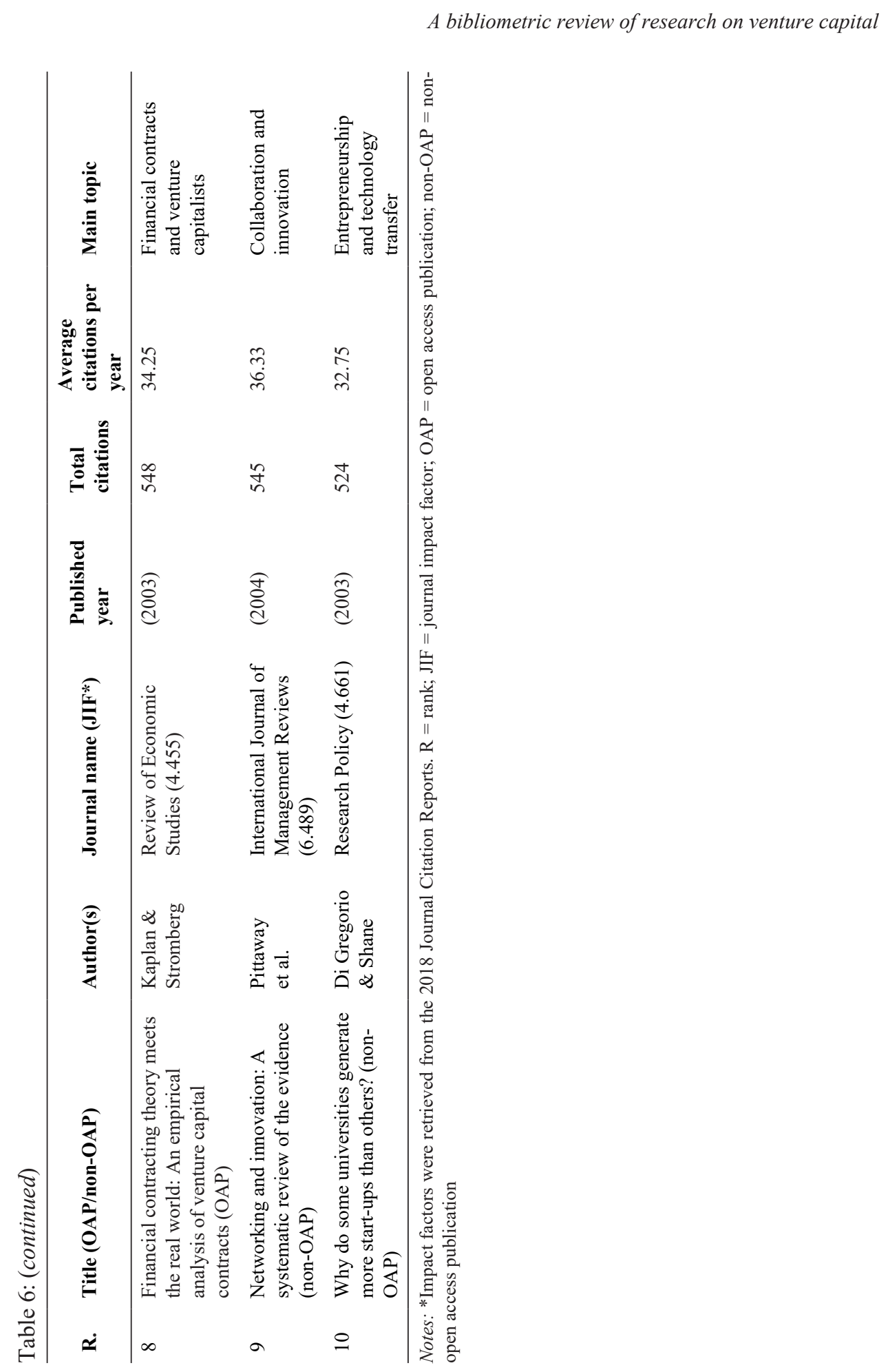




\section{Co-citation analysis}

If authors are included in the reference lists or are co-cited, it means that there is a relationship or interaction between two publications. The more two publications are cited together, the more similarities between them can be assumed (van Nunen et al., 2018). A threshold of 20 citations was adopted out of a total of 1,656 publications on venture capital to analyse the co-citation aspect. It is important to note that the publications that did not contain the references were overlooked (Table 2). In these publications, a total of 90,247 references were used, with an average of 49 references per publication, but the number of unique references used was 46,750 references. As a result, only 393 references met the adopted threshold.

Figure 8 shows the co-citation analysis results obtained by VOSviewer. The circle size represents the number of citations, while the distance between two circles indicates the relationship strength between two publications or the similarities between them. Circles with the same colour suggest a similar topic among them. The co-citation map is divided into five clusters where every cluster represents a research subfield in venture capital research. The red cluster has 117 items, the green cluster has 95 items, the blue cluster has 75 items, the yellow cluster has 68 items, and the purple cluster has 36 items. It is clear that the five groups are intertwined. Therefore, the more intertwined the clusters are, the more correlated the research fields are. After examining the title and abstract of each publication in the five clusters, an appropriate title could be assigned to each of them. In short, these clusters (the red, green, blue, yellow, and purple) represent the following subfields respectively: venture capital networks, venture capital funding determinants and contracting framework, venture capitalists' investments activities, venture capital selection function, and IPO of venture capital backed companies.

According to the results, the red cluster references have an important influence in venture capital research. However, "Syndication networks and the spatial distribution of venture capital investments" by Sorenson and Stuart (2001), "Whom you know matters: Venture capital networks and investment performance" by Hochberg et al. (2007), and "Interorganizational endorsements and the performance of entrepreneurial ventures" by Stuart et al. (1999) can be considered as the most influential references in this cluster. Similarly, the publications from the green cluster have an important influence as well; five references from this cluster can be consulted among the 10 most cited publications in the field of venture capital research. These publications are "The structure and governance of venture-capital organizations" by Sahlman (1990), "Venture capital and the professionalization of start-up firms: Empirical evidence" by Hellmann and Puri (2002), and "Financial contracting theory meets the real world: An empirical analysis of venture capital 
contracts" by Kaplan and Strömberg (2003); in addition to "The syndication of venture capital investments" by Lerner (1994) and "What drives venture capital fundraising?" by Gompers and Lerner (1998).

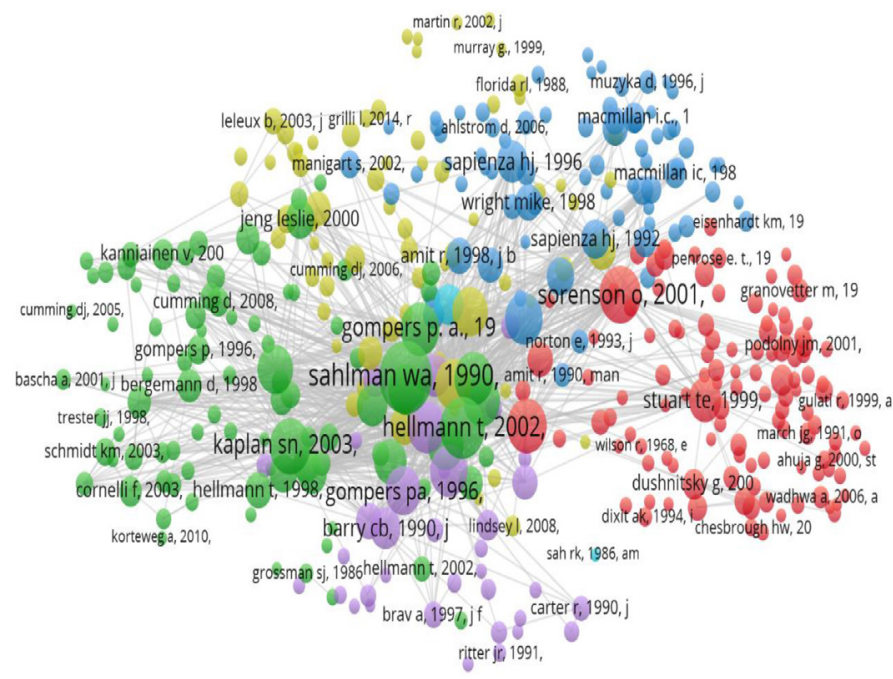

Figure 8. Co-citation analysis of highly-cited references used in venture capital publications

In the other two clusters (blue and yellow), there is only one reference in each cluster that can be considered as the most influential reference: "What do venture capitalists do?" by Gorman and Sahlman (1989) in the blue cluster and "Assessing the contribution of venture capital to innovation" by Kortum and Lerner (2000) in the yellow cluster. Finally and despite its smaller size, the purple cluster contains two influential references: "Venture capitalist certification in initial public offerings" by Megginson and Weiss (1991) and "Venture capitalists and the oversight of private firms" by Lerner (1995). As a result, these clusters are intertwined due to the authors' influence that appears in more than a cluster. For example, Sahlman has an influential publication in the green and blue clusters, as well as Lerner where he appears in the green, yellow, and purple clusters. Those authors are used as references in different clusters, and their papers are published in different venture capital research subfields.

\section{Term analysis}

The visualisation and analysis of terms used in the venture capital domain provide insight into main topics and trends in venture capital research. VOSviewer was used to build the term network, where 25,036 terms were extracted from the titles 
and abstracts of the study sample. After verifying the terms, terms with a general meaning, such as "vol", "author", "hypothesis", and "iii", were excluded, and terms with similar meanings were merged, such as "venture capital funding" and "VC funding". The relevance score was calculated, and based on this score, $60 \%$ of the most relevant terms were considered. Terms that occurred only in at least 10 publications were considered; 377 terms met this limitation.

Figure 9 represents the venture capital terms analysis network, where the circle size indicates the occurrences of the terms, and the distance between them in the visualisation network indicates the relatedness or the similarity. It can be said that any decrease in the distance between the terms can result into a strong relatedness between them (van Nunen et al., 2018), i.e., greater relatedness means that terms occur much more together in the title and abstract than other terms.

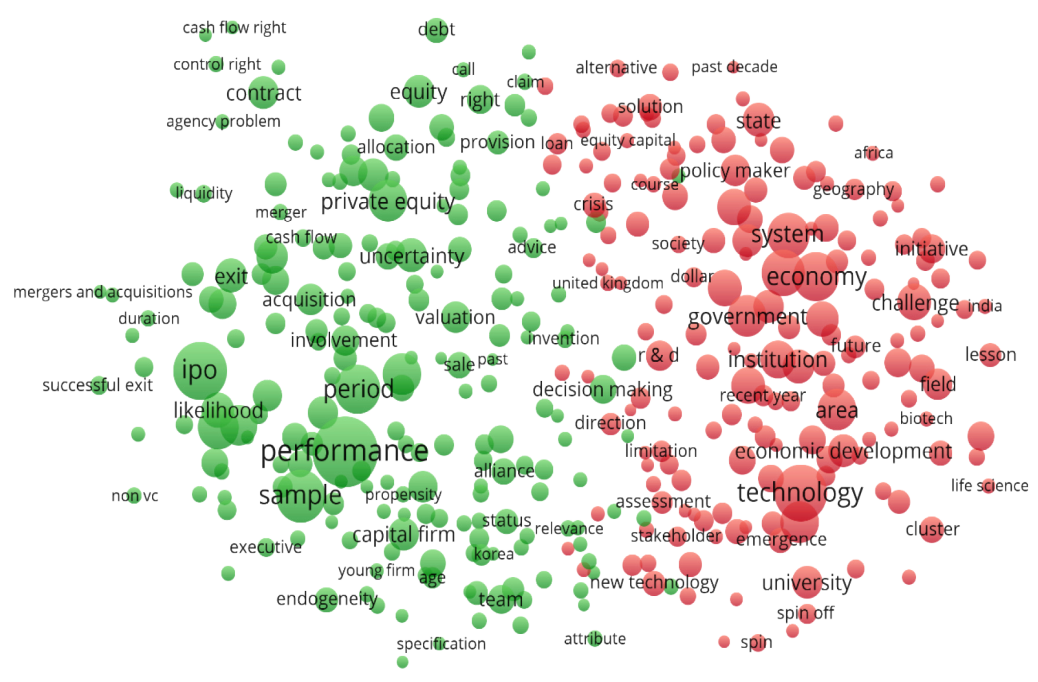

Figure 9. Venture capital terms analysis network

The terms in the map shows two main clusters; each cluster represents a level of venture capital analysis. The first cluster (red) includes venture capital topics at the macro-level. The most common terms in this cluster are: technology, economy, system, area, government, institution, policy, and state. In addition, the analysis of the red cluster terms indicates that the research at this level focuses on how to establish a venture capital market, the impact of venture capital on the economy, and the role of government, universities, private sector, and research and development on this market. Moreover, the most cited publications at this level are those by 
Bruton and Ahlstrom (2003), Hall (2002), Hellmann and Puri (2000), Kortum and Lerner (2000), Wright et al. (2002), Wright et al. (2005), and Cumming (2007).

The second cluster (green) includes terms such as performance, sample, IPO, period, private equity, equity, exit, contract, uncertainty, and valuation. This analysis level contains several topics. Firm performance seems to be the most common topic among researchers. The venture capital funds performance can be measured by successful exits through an IPO (Hochberg et al., 2007). The green cluster also contains terms that are related to aspects of the financial contracting theory (Kaplan \& Strömberg, 2003), such as "uncertainty", "contract", "control rights", and "agency problem". Topics from the green cluster seem to be more practical-oriented emphases. Therefore, terms such as "period" and "sample" occur largely and have a strong relatedness with the most relevant terms in this cluster. The most cited publications within the green cluster are those by Cumming (2007, 2008), Lee et al. (2001), Podolny (2001), Shane and Stuart (2002), and Sorenson and Stuart (2001).

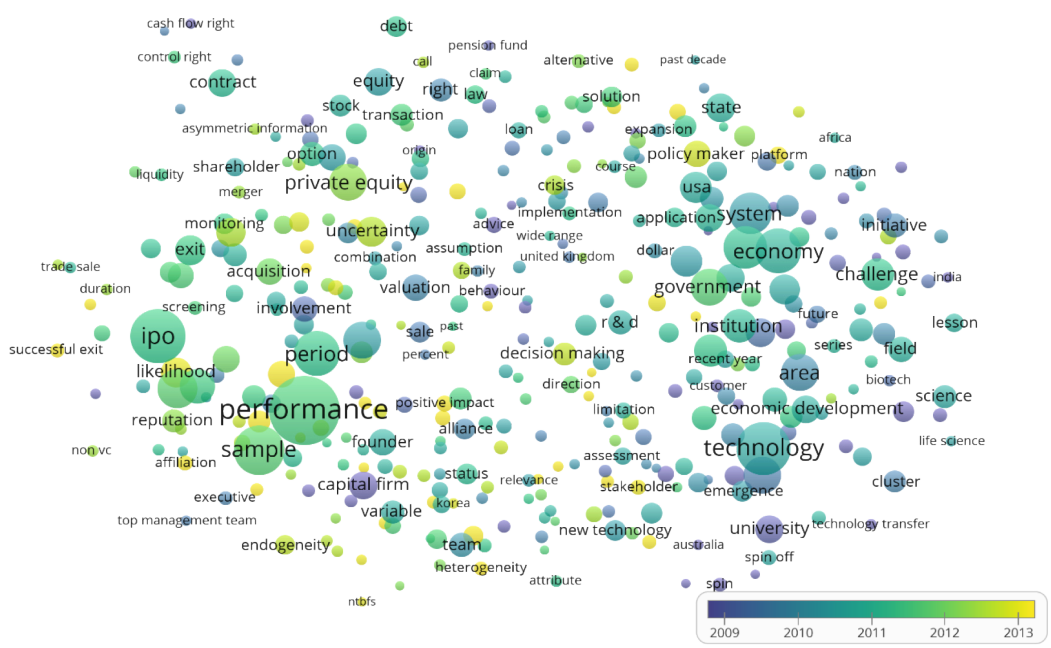

Figure 10. Venture capital publication terms analysis by time information

Figure 10 shows the map of the term analysis based on time information. The colour indicates the average year of publication of the term. By analysing the terms by time information, it can be noted that the macro level of venture capital received a lot of attention before 2011, while, after the same period most research was conducted at the micro level. This switch from macro to micro-level issues can be attributed to the governments' understanding of the importance of the venture capital market, and the emergence of a new venture capital market with 
new problematic at the micro level of venture capital industry. However, this does not mean that less attention is paid to research at the macro level after 2011. This is proven by the fact that there are terms at this level around 2013, but the micro level dominates.

Given the new terms in yellow circles, whose names often do not appear from VOSviewer only after zooming in, it can be observed that there is a mixture between the two levels of research. Most of the research around 2013 was focused on empirical methods (corresponding terms such as likelihood, datasets, heterogeneity, positive impact), innovation (corresponding terms such as technological innovation, innovative activity), the support decision-makers where last publications focused on group decision making, multi-attribute decision making, and multi-criteria decision making (corresponding terms such as decision making, uncertainty). Moreover, recent research tends to combine communication within venture capital network, represented by signal theory (corresponding terms such as signal, asymmetric information), with venture capital variables, such as "performance", "innovation", "quality", "social network", "syndication", "alliances", "early-stage entrepreneurial", "patents", "IPO", and "spin-out companies". In addition, the latest research studies were on crowdfunding (around 2017); it represents a new investment strategy where the most related terms are "policy maker", "platforms", and "regulation". It should be noted that there is a complete absence of terms related to blockchain technology, which has recently been recognised as one of the major emerging technologies (Friedlmaier et al., 2018), and which could begin to revolutionise entrepreneurship and innovation (Chen, 2018). A future survey on the impacts of the blocking chain on the development prospects of venture capital is therefore necessary.

\section{CONCLUSION AND LIMITATIONS OF THE STUDY}

This paper aimed to provide an overview picture of venture capital research from 2000 to 2018 using the WOS database. Venture capital has become a relevant topic, especially in recent years, due to its contribution to the success of startups and innovative projects. This study was carried out on 1,840 publications on venture capital covering 2,607 authors, 518 journals, 66 countries or territories, and 1,280 institutions. An overview of the main characteristics of the venture capital literature based on a bibliometric analysis was carried out to provide decisionmaking support in the context of venture capital research management. The results indicate that over the last decade, the number of venture capital research publications has been steadily increasing. In addition, the very large number of co-authored publications is indicative of a high degree of collaboration between 
researchers in this field of research. Cumming and Wright are the most productive authors on the topic of venture capital. Both authors are from the two main clusters of the authors' cooperation network, which means the other authors in the same field are directly or indirectly linked to one of them.

Two levels of analysis can be distinguished in the venture capital research field: macro and micro. Initially, research at the macro level focused on how to establish a venture capital market, the impact of venture capital on the economy and the role of government, universities, private sector, and research and development on this market. On the other hand, research at the micro level focused on topics related to the operational activities of venture capital market factors. The micro level now occupies a dominant position in venture capital research. Moreover, new research areas have focused especially on the implication of the signal theory in venture capital networks, support for decision-makers and crowdfunding as a new investment strategy.

In terms of countries and languages, most of the venture capital publications are published in the English language, as it is the international language and allows authors to proffer their publications. As expected, the USA is the country with the highest number of publications, followed by the UK and Canada. As a result, Harvard University is the most productive institution with 59 publications. The Asian territory is attracting more and more attention, especially, in China that the novelty of its publications and its inspiration to do venture capital research will make it a major player in the venture capital field.

The most active journal is the Journal of Business Venturing with 92 publications, Small Business Economic with 65 publications and the Journal of Corporate Finance with 47 publications. The majority of the contributions appear under "business" and "management" as a subject category. The analysis proved that the main topic related to venture capital is entrepreneurship. The American Journal of Sociology is the journal that publishes the most cited publication, and non-OAP represent $90 \%$ of all publications, and $85 \%$ of total citations of these publications. However, OAPs' contribution to citations is greater than their contribution to the number of publications.

Despite the good results obtained, this study has two main limitations. The first, which is considered inherent, is related to the WOS database and bibliometric method. The problem of missing data is the crucial limitation, and ignoring it can confuse researchers when using bibliometric results to evaluate research. However, to minimise this risk, we listed the missing data from the WOS database in Table 2 and mentioned it whenever it had to be done in this study. Regarding 
the inherent limitations of the bibliometric method, the tendency to evaluate research by data rather than by judgment represents the most relevant sources of bias in bibliometric analysis. Therefore, reviewers should be used with caution as bibliometric analysis may favour older researchers and older research (Lane, 2010; Wang et al., 2017), and the high number of citations does not necessarily reflect a high impact on scientific results (Criscuolo \& Verspagen, 2008; Drew et al., 2016). To this end, we discussed quantitative measures under different indicators surrounding venture capital publications. For example, we analysed countries in terms of authors' affiliation and country-related research. In addition, we adopted an average of citations per year to allow us to include recent high-impact publications. Second, with respect to the limitations related to the type of study and its objectives, we presented only the first ten of the most influential items. Also, we chose the minimum threshold in the creation of network visualisation of coauthorship, co-citation, and co-occurrence. Moreover, our results are restricted to the only contributions indexed in the WOS.

Given these limitations, the results of the bibliometric analysis confirm that venture capital will continue to attract the interest of a wide range of researchers and practitioners. Therefore, this paper provides both theoretical implications for researchers and practical implications for policymakers and the general public. In terms of theoretical implications, the findings of this bibliometric analysis provide relevant and useful insights that allow scholars to define areas for the future. Since the publication of the first studies, a trend can be observed and characterised by exploring the role played by governments in fostering venture capital markets. During this period, research has focused more on the importance of venture capital and its impact on the economy. However, recent works focus more on the operational activities of venture capital firms and how successful projects are chosen and funded. This study informs the researcher on the methodological choices and bibliography that should be used in relation to the areas that could be further developed.

In terms of practical implications, the results of this study can be used effectively to evaluate and manage research. The bibliometric methodology applied in this study makes it possible to evaluate large number of publications from different institutions and countries. Our findings can then be used as a basis for decision-making and for assessing the performance of funding agencies and research institutions. The visualisations of our study could serve as a policy tool for the identification of international experiences, also, it could be a guide for policymakers in emerging venture capital markets by highlighting the area of interest of more developed venture capital markets, and then predict the type of problems their markets will face in the very near future. 


\section{ACKNOWLEDGEMENTS}

This research was funded by General Directorate of Scientific Research and Technological Development, Ministry of Higher Education and Scientific Research, Algeria. The authors declare no conflict of interest.

\section{REFERENCES}

Abramo, G., D’Angelo, C. A., \& Caprasecca, A. (2009). Allocative efficiency in public research funding: Can bibliometrics help? Research Policy, 38(1), 206-215. https://doi.org/10.1016/j.respol.2008.11.001

Anderson, H. D., Chi, J., \& Wang, Q. S. (2017). Political ties and VC exits: Evidence from China. China Economic Review, 44, 48-66. https://doi.org/10.1016/j. chieco.2017.03.007

Anwar, S., Abdullah, F. M., Alkahtani, M. S., Ahmad, S., \& Alatefi, M. (2019). Bibliometric analysis of abrasive water jet machining research. Journal of King Saud University-Engineering Sciences, 31(3), 262-270. https://doi.org/10.1016/j. jksues.2018.02.002

Arshad, M., Bano, I., Khan, N., Shahzad, M. I., Younus, M., Abbas, M., \& Iqbal, M. (2018). Electricity generation from biogas of poultry waste: An assessment of potential and feasibility in Pakistan. Renewable and Sustainable Energy Reviews, 81, 1241-1246. https://doi.org/10.1016/j.rser.2017.09.007

Baldi, F., Baglieri, D., \& Corea, F. (2015). Balancing risk and learning opportunities in corporate venture capital investments: Evidence from the biopharmaceutical industry. Entrepreneurship Research Journal, 5(3), 221-250. https://doi. org/10.1515/erj-2014-0036

Barry, C. B., Muscarella, C. J., Peavy III, J. W., \& Vetsuypens, M. R. (1990). The role of venture capital in the creation of public companies: Evidence from the goingpublic process. Journal of Financial Economics, 27(2), 447-471. https://doi. org/10.1016/0304-405X(90)90064-7

Batjargal, B. (2007). Network triads: Transitivity, referral and venture capital decisions in China and Russia. Journal of International Business Studies, 38(6), 998-1012. https://doi.org/10.1057/palgrave.jibs.8400302

Batjargal, B., \& Liu, M. (2004). Entrepreneurs' access to private equity in China: The role of social capital. Organization Science, 15(2), 159-172. https://doi.org/10.1287/ orsc. 1030.0044

Bhargava, P. M. (2016). Scientific research and economic development. Social Change, 46(2), 260-266. https://doi.org/10.1177/0049085716635403

Bhatt, P., \& Ahmad, A. J. (2017). Financial social innovation to engage the economically marginalized: Insights from an Indian case study. Entrepreneurship \& Regional Development, 29(5-6), 391-413. https://doi.org/10.1080/08985626.2017.1287961

Bjerke, B., \& Hultman, C. (2004). Entrepreneurial marketing: The growth of small firms in the new economic era. Cheltenham, UK: Edward Elgar Publishing. 
Bornmann, L., \& Daniel, H. D. (2008). What do citation counts measure? A review of studies on citing behavior. Journal of Documentation, 64(1), 45-80. https://doi. org/10.1108/00220410810844150

Bornmann, L., Mutz, R., Neuhaus, C., \& Daniel, H.-D. (2008). Citation counts for research evaluation: standards of good practice for analyzing bibliometric data and presenting and interpreting results. Ethics in Science and Environmental Politics, 8(1), 93-102. https://doi.org/10.3354/esep00084

Brander, J. A., Amit, R., \& Antweiler, W. (2002). Venture-capital syndication: Improved venture selection vs. the value-added hypothesis. Journal of Economics \& Management Strategy, 11(3), 423-452. https://doi.org/10.1111/j.14309134.2002.00423.x

Bruton, G., Ahlstrom, D., \& Yeh, K. S. (2004). Understanding venture capital in East Asia: The impact of institutions on the industry today and tomorrow. Journal of World Business, 39(1), 72-88. https://doi.org/10.1016/j.jwb.2003.08.002

Bruton, G. D., \& Ahlstrom, D. (2003). An institutional view of China's venture capital industry: Explaining the differences between China and the West. Journal of Business Venturing, 18(2), 233-259. https://doi.org/10.1016/S08839026(02)00079-4

Bruton, G. D., Ahlstrom, D., \& Puky, T. (2009). Institutional differences and the development of entrepreneurial ventures: A comparison of the venture capital industries in Latin America and Asia. Journal of International Business Studies, 40(5), 762-778. https://doi.org/10.1057/jibs.2009.3

Butler, L. (2003). Explaining Australia's increased share of ISI publications: The effects of a funding formula based on publication counts. Research Policy, 32(1), 143-155. https://doi.org/10.1016/S0048-7333(02)00007-0

Cancino, C. A., Merigo, J. M., Torres, J. P., \& Diaz, D. (2018). A bibliometric analysis of venture capital research. Journal of Economics, Finance and Administrative Science, 23(45), 182-195. https://doi.org/10.1108/JEFAS-01-2018-0016

Cargill, M., \& O'Connor, P. (2006). Developing Chinese scientists' skills for publishing in English: Evaluating collaborating-colleague workshops based on genre analysis. Journal of English for Academic Purposes, 5(3), 207-221. https://doi. $\operatorname{org} / 10.1016 /$ j.jeap.2006.07.002

Case, D. O., \& Higgins, G. M. (2000). How can we investigate citation behavior? A study of reasons for citing literature in communication. Journal of the American Society for Information Science, 51(7), 635-645. https://doi.org/10.1002/(SICI)10974571(2000)51:7\%3C635::AID-ASI6\%3E3.0.CO;2-H

Chen, Y. (2018). Blockchain tokens and the potential democratization of entrepreneurship and innovation. Business Horizons, 61(4), 567-575. https://doi.org/10.1016/j. bushor.2018.03.006

Cho, J., \& Lee, J. (2013). The venture capital certification role in R\&D: Evidence from IPO underpricing in Korea. Pacific-Basin Finance Journal, 23, 83-108. https:// doi.org/10.1016/j.pacfin.2013.01.005

Cornelius, B., \& Persson, O. (2006). Who's who in venture capital research. Technovation, 26(2), 142-150. https://doi.org/10.1016/j.technovation.2005.05.009 
Criscuolo, P., \& Verspagen, B. (2008). Does it matter where patent citations come from? Inventor vs. examiner citations in European patents. Research Policy, 37(10), 1892-1908. https://doi.org/10.1016/j.respol.2008.07.011

Cumming, D. (2007). Government policy towards entrepreneurial finance: Innovation investment funds. Journal of Business Venturing, 22(2), 193-235. https://doi. org/10.1016/j.jbusvent.2005.12.002

Cumming, D. (2008). Contracts and exits in venture capital finance. Review of Financial Studies, 21(5), 1947-1982. https://doi.org/10.1093/rfs/hhn072

Cumming, D., \& Zhang, Y. (2016). Alternative investments in emerging markets: A review and new trends. Emerging Markets Review, 29, 1-23. https://doi.org/10.1016/j. ememar.2016.08.022

Cumming, D. J., \& Johan, S. A. (2013). Venture capital and private equity contracting: An international perspective. Cambridge, MA: Academic Press.

Curry, M. J., \& Lillis, T. (2004). Multilingual scholars and the imperative to publish in English: Negotiating interests, demands, and rewards. TESOL Quarterly, 38(4), 663-688. https://doi.org/10.2307/3588284

Dai, N., Jo, H., \& Kassicieh, S. (2012). Cross-border venture capital investments in Asia: Selection and exit performance. Journal of Business Venturing, 27(6), 666-684. https://doi.org/10.1016/j.jbusvent.2011.04.004

Dettenhofer, M., Ondrejovič, M., Vásáry, V., Kaszycki, P., Twardowski, T., Stuchlík, S., Turňa, J., Dundar, M., Gartland, K. M., \& Miertuš, S. (2019). Current state and prospects of biotechnology in Central and Eastern European countries. Part I: Visegrad countries (CZ, H, PL, SK). Critical Reviews in Biotechnology, 39(1), 114-136. https://doi.org/10.1080/07388551.2018.1523131

Devigne, D., Manigart, S., Vanacker, T., \& Mulier, K. (2018). Venture capital internationalization: Synthesis and future research directions. Journal of Economic Surveys, 32(5), 1414-1445. https://doi.org/10.1111/joes.12276

Di Gregorio, D., \& Shane, S. (2003). Why do some universities generate more start-ups than others? Research Policy, 32(2), 209-227. https://doi.org/10.1016/S00487333(02)00097-5

Dossani, R., \& Kenney, M. (2002). Creating an environment for venture capital in India. World Development, 30(2), 227-253. https://doi.org/10.1016/S0305750X(01)00110-3

Drew, C. H., Pettibone, K. G., Finch, F. O., Giles, D., \& Jordan, P. (2016). Automated research impact assessment: A new bibliometrics approach. Scientometrics, 106(3), 987-1005. https://doi.org/10.1007/s11192-015-1828-7

Drover, W., Busenitz, L., Matusik, S., Townsend, D., Anglin, A., \& Dushnitsky, G. (2017). A review and road map of entrepreneurial equity financing research: Venture capital, corporate venture capital, angel investment, crowdfunding, and accelerators. Journal of Management, 43(6), 1820-1853. https://doi. org/10.1177/0149206317690584

Dushnitsky, G., \& Lenox, M. J. (2005). When do incumbents learn from entrepreneurial ventures? Corporate venture capital and investing firm innovation rates. Research Policy, 34(5), 615-639. https://doi.org/10.1016/j.respol.2005.01.017 
Elango, B., Fried, V. H., Hisrich, R. D., \& Polonchek, A. (1995). How venture capital firms differ. Journal of Business Venturing, 10(2), 157-179. https://doi. org/10.1016/0883-9026(94)00019-Q

Ferrary, M. (2011). Specialized organizations and ambidextrous clusters in the open innovation paradigm. European Management Journal, 29(3), 181-192. https:// doi.org/10.1016/j.emj.2010.10.007

Ferrary, M., \& Granovetter, M. (2009). The role of venture capital firms in Silicon Valley's complex innovation network. Economy and Society, 38(2), 326-359. https://doi. org $/ 10.1080 / 03085140902786827$

Florida, R., \& Smith Jr, D. F. (1990). Venture capital, innovation, and economic developmemt. Economic Development Quarterly, 4(4), 345-360. https://doi. org/10.1177/089124249000400405

Flowerdew, J. (2001). Attitudes of journal editors to nonnative speaker contributions. TESOL Quarterly, 35(1), 121-150. https://doi.org/10.2307/3587862

Flowerdew, J. (2008). Scholarly writers who use English as an Additional Language: What can Goffman's “Stigma” tell us? Journal of English for Academic Purposes, 7(2), 77-86. https://doi.org/10.1016/j.jeap.2008.03.002

Franceschini, F., Maisano, D., \& Mastrogiacomo, L. (2016). Empirical analysis and classification of database errors in Scopus and Web of Science. Journal of Informetrics, 10(4), 933-953. https://doi.org/10.1016/j.joi.2016.07.003

Friedlmaier, M., Tumasjan, A., \& Welpe, I. M. (2018). Disrupting industries with blockchain: The industry, venture capital funding, and regional distribution of blockchain ventures. Paper presented at the Venture Capital Funding, and Regional Distribution of Blockchain Ventures (22 September 2017). Proceedings of the 51st Annual Hawaii International Conference on System Sciences (HICSS). https://doi.org/10.24251/HICSS.2018.445

Gilson, R. J. (2002). Engineering a venture capital market: Lessons from the American experience. Stan. L. Rev., 55, 1067. https://doi.org/10.2139/ssrn. 353380

Gompers, P. A., \& Lerner, J. (1998). What drives venture capital fundraising? Brookings Papers on Economic Activity. Microeconomics, 149-204. https://doi. org/10.2307/2534802

Gompers, P. A., \& Lerner, J. (2004). The venture capital cycle. Cambridge, MA: MIT Press.

González-Uribe, J. (2020). Exchanges of innovation resources inside venture capital portfolios. Journal of Financial Economics, 135(1), 144-168. https://doi. org/10.1016/j.jfineco.2019.05.017

Gorman, M., \& Sahlman, W. A. (1989). What do venture capitalists do? Journal of Business Venturing, 4(4), 231-248. https://doi.org/10.1016/0883-9026(89)90014-1

Hall, B. H. (2002). The financing of research and development. Oxford Review of Economic Policy, 18(1), 35-51. https://doi.org/10.1093/oxrep/18.1.35

Harnad, S., \& Brody, T. (2004). Comparing the impact of open access (OA) vs. non-OA articles in the same journals. D-lib Magazine, 10(6). 
Harrison, R., Scheela, W., Lai, P., \& Vivekarajah, S. (2018). Beyond institutional voids and the middle-income trap: The emerging business angel market in Malaysia. Asia Pacific Journal of Management, 35(4), 965-991. https://doi.org/10.1007/ s10490-017-9535-y

Harrison, R. T., \& Mason, C. M. (2019). Venture capital 20 years on: Reflections on the evolution of a field. Venture Capital, 21(1), 1-34. https://doi.org/10.1080/13691 066.2019 .1562627

Hellmann, T. (2006). IPOs, acquisitions, and the use of convertible securities in venture capital. Journal of Financial Economics, 81(3), 649-679. https://doi.org/10 $.1016 /$ j.jfineco.2005.06.007

Hellmann, T., \& Puri, M. (2000). The interaction between product market and financing strategy: The role of venture capital. The Review of Financial Studies, 13(4), 959-984. https://doi.org/10.1093/rfs/13.4.959

Hellmann, T., \& Puri, M. (2002). Venture capital and the professionalization of start-up firms: Empirical evidence. The Journal of Finance, 57(1), 169-197. https://doi. org/10.1111/1540-6261.00419

Hicks, D., Wouters, P., Waltman, L., De Rijcke, S., \& Rafols, I. (2015). Bibliometrics: The Leiden Manifesto for research metrics. Nature, 520(7548), 429-431. https://doi. org/10.1038/520429a

Hill, S. A., \& Birkinshaw, J. (2014). Ambidexterity and survival in corporate venture units. Journal of Management, 40(7), 1899-1931. https://doi. org/10.1177/0149206312445925

Hochberg, Y. V., Ljungqvist, A., \& Lu, Y. (2007). Whom you know matters: Venture capital networks and investment performance. The Journal of Finance, 62(1), 251-301. https://doi.org/10.1111/j.1540-6261.2007.01207.x

Houben, A., \& Kakes, J. (2002). ICT innovation and economic performance: The role of financial intermediation. Kyklos, 55(4), 543-562. https://doi.org/10.1111/14676435.00201

Indergaard, M. (2003). The webs they weave: Malaysia's multimedia super-corridor and New York city's Silicon Alley. Urban Studies, 40(2), 379-401. https://doi. org/10.1080/00420980220080321

Jung, K., Eun, J.-H., \& Lee, S.-H. (2017). Exploring competing perspectives on governmentdriven entrepreneurial ecosystems: Lessons from Centres for Creative Economy and Innovation (CCEI) of South Korea. European Planning Studies, 25(5), 827847. https://doi.org/10.1080/09654313.2017.1282083

Kaplan, S. N., \& Strömberg, P. (2003). Financial contracting theory meets the real world: An empirical analysis of venture capital contracts. The Review of Economic Studies, 70(2), 281-315. https://doi.org/10.1111/1467-937X.00245

Karaulova, M., Gök, A., Shackleton, O., \& Shapira, P. (2016). Science system pathdependencies and their influences: Nanotechnology research in Russia. Scientometrics, 107(2), 645-670. https://doi.org/10.1007/s11192-016-1916-3

Kim, Y., \& Heshmati, A. (2010). Analysis of Korean IT startups' initial public offering and their post-IPO performance. Journal of Productivity Analysis, 34(2), 133-149. https://doi.org/10.1007/s11123-010-0176-0 
Klingler-Vidra, R. (2014). Building a venture capital market in Vietnam: diffusion of a neoliberal market strategy to a socialist state. Asian Studies Review, 38(4), 582600. https://doi.org/10.1080/10357823.2014.958054

Knockaert, M., Clarysse, B., \& Wright, M. (2010). The extent and nature of heterogeneity of venture capital selection behaviour in new technology-based firms. $R \& D$ Management, 40(4), 357-371. https://doi.org/10.1111/j.1467-9310.2010.00607.x

Köhn, A. (2018). The determinants of startup valuation in the venture capital context: A systematic review and avenues for future research. Management Review Quarterly, 68(1), 3-36. https://doi.org/10.1007/s11301-017-0131-5

Kortum, S., \& Lerner, J. (1998). Does venture capital spur innovation? (0898-2937). NBER Working Paper Series, No. 6846. https://doi.org/10.3386/w6846

Kortum, S., \& Lerner, J. (2000). Assessing the contribution of venture capital to innovation. RAND Journal of Economics, 674-692. https://doi.org/10.2307/2696354

Kung, C.-Y., \& Wen, K.-L. (2007). Applying grey relational analysis and grey decisionmaking to evaluate the relationship between company attributes and its financial performance: A case study of venture capital enterprises in Taiwan. Decision Support Systems, 43(3), 842-852. https://doi.org/10.1016/j.dss.2006.12.012

Landstrom, H. (2007). Pioneers in entrepreneurship and small business research (International Studies in Entrepreneurship, vol. 8). USA: Springer.

Landström, H. (2007). Handbook of research on venture capital. Cheltenham, UK: Edward Elgar Publishing. https://doi.org/10.4337/9781847208781

Lane, J. (2010). Let's make science metrics more scientific. Nature, 464(7288), 488-489. https://doi.org/10.1038/464488a

Lee, C., Lee, K., \& Pennings, J. M. (2001). Internal capabilities, external networks, and performance: A study on technology-based ventures. Strategic Management Journal, 22(6-7), 615-640. https://doi.org/10.1002/smj.181

Lee, P. M., \& Wahal, S. (2004). Grandstanding, certification and the underpricing of venture capital backed IPOs. Journal of Financial Economics, 73(2), 375-407. https://doi.org/10.1016/j.jfineco.2003.09.003

Lehrer, M., \& Asakawa, K. (2004). Rethinking the public sector: idiosyncrasies of biotechnology commercialization as motors of national R\&D reform in Germany and Japan. Research Policy, 33(6-7), 921-938. https://doi.org/10.1016/j. respol.2004.01.011

Lerner, J. (1994). The syndication of venture capital investments. Financial Management, 16-27. https://doi.org/10.2307/3665618

Lerner, J. (1995). Venture capitalists and the oversight of private firms. The Journal of Finance, 50(1), 301-318. https://doi.org/10.1111/j.1540-6261.1995.tb05175.x

Li, J., \& Hale, A. (2015). Identification of, and knowledge communication among core safety science journals. Safety Science, 74, 70-78. https://doi.org/10.1016/j. ssci.2014.12.003

Li, Y., \& Flowerdew, J. (2007). Shaping Chinese novice scientists' manuscripts for publication. Journal of Second Language Writing, 16(2), 100-117. https://doi. org/10.1016/j.jslw.2007.05.001

Lim, S., \& Kim, Y. (2015). How to design public venture capital funds: Empirical evidence from South Korea. Journal of Small Business Management, 53(4), 843-867. https://doi.org/10.1111/jsbm.12109 
Liu, W., Ding, Y., \& Gu, M. (2017). Book reviews in academic journals: Patterns and dynamics. Scientometrics, 110(1), 355-364. https://doi.org/10.1007/s11192-0162172-2

Liu, W., Hu, G., \& Tang, L. (2018). Missing author address information in Web of Science: An explorative study. Journal of Informetrics, 12(3), 985-997. https:// doi.org/10.1016/j.joi.2018.07.008

Liu, X., Zhan, F. B., Hong, S., Niu, B., \& Liu, Y. (2013). Replies to comments on "a bibliometric study of earthquake research: 19003-2010". Scientometrics, 96(3), 933-936. https://doi.org/10.1007/s11192-012-0914-3

Lu, Q., \& Hwang, P. (2010). The impact of liability of foreignness on international venture capital firms in Singapore. Asia Pacific Journal of Management, 27(1), 81-97. https://doi.org/10.1007/s10490-008-9125-0

Lynskey, M. J. (2004). Determinants of innovative activity in Japanese technology-based start-up firms. International Small Business Journal, 22(2), 159-196. https://doi. org/10.1177/0266242604041312

Ma, S. (2020). The life cycle of corporate venture capital. The Review of Financial Studies, 33(1), 358-394. https://doi.org/10.1093/rfs/hhz042

Malekdar, M. (2012). Strategic analysis of the presence of corporate venture capital in Iranian Science and Technology Parks Incubators. Life Science Journal, 9(3).

Mani, S. (2004). Institutional support for investment in domestic technologies: An analysis of the role of government in India. Technological Forecasting and Social Change, 71(8), 855-863. https://doi.org/10.1016/j.techfore.2004.01.011

Martín-Martín, A., Orduna-Malea, E., Thelwall, M., \& López-Cózar, E. D. (2018). Google Scholar, Web of Science, and Scopus: A systematic comparison of citations in 252 subject categories. Journal of Informetrics, 12(4), 1160-1177. https://doi. org/10.1016/j.joi.2018.09.002

Mayer, C., Schoors, K., \& Yafeh, Y. (2005). Sources of funds and investment activities of venture capital funds: Evidence from Germany, Israel, Japan and the United Kingdom. Journal of Corporate Finance, 11(3), 586-608. https://doi. org/10.1016/j.jcorpfin.2004.02.003

McKinley, J., \& Rose, H. (2018). Conceptualizations of language errors, standards, norms and nativeness in English for research publication purposes: An analysis of journal submission guidelines. Journal of Second Language Writing, 42, 1-11. https://doi.org/10.1016/j.jslw.2018.07.003

Megginson, W. L., \& Weiss, K. A. (1991). Venture capitalist certification in initial public offerings. The Journal of Finance, 46(3), 879-903. https://doi. org/10.1111/j.1540-6261.1991.tb03770.x

Meuleman, M., Jääskeläinen, M., Maula, M. V., \& Wright, M. (2017). Venturing into the unknown with strangers: Substitutes of relational embeddedness in cross-border partner selection in venture capital syndicates. Journal of Business Venturing, 32(2), 131-144. https://doi.org/10.1016/j.jbusvent.2017.01.001

Milojević, S. (2014). Network analysis and indicators. In Y. Ding, R. Rousseau, \& D. Wolfram (Eds.), Measuring scholarly impact (pp. 57-82). Cham: Springer International Publishing. https://doi.org/10.1007/978-3-319-10377-8_3 
Minola, T., \& Giorgino, M. (2008). Who's going to provide the funding for high tech start-ups? A model for the analysis of determinants with a fuzzy approach. $R \& D$ Management, 38(3), 335-351. https://doi.org/10.1111/j.1467-9310.2008.00518.x

Mitteness, C., Sudek, R., \& Cardon, M. S. (2012). Angel investor characteristics that determine whether perceived passion leads to higher evaluations of funding potential. Journal of Business Venturing, 27(5), 592-606. https://doi.org/10.1016/j. jbusvent.2011.11.003

Moher, D., Naudet, F., Cristea, I. A., Miedema, F., Ioannidis, J. P., \& Goodman, S. N. (2018). Assessing scientists for hiring, promotion, and tenure. PLoS Biology, 16(3), e2004089. https://doi.org/10.1371/journal.pbio.2004089

Mongeon, P., \& Paul-Hus, A. (2016). The journal coverage of Web of Science and Scopus: A comparative analysis. Scientometrics, 106(1), 213-228. https://doi.org/10.1007/ s11192-015-1765-5

$\mathrm{Mu}, \mathrm{C}$. (2020). Controversial issues in ERPP studies. In: Understanding Chinese multilingual scholars' experiences of writing and publishing in English (pp. 45-66). London: Plagrave MacMillan, Cham. https://doi.org/10.1007/978-3-03033938-8 3

Narayanan, V., Yang, Y., \& Zahra, S. A. (2009). Corporate venturing and value creation: A review and proposed framework. Research Policy, 38(1), 58-76. https://doi. org/10.1016/j.respol.2008.08.015

Newman, M. E. (2003). The structure and function of complex networks. SIAM Review, 45(2), 167-256. https://doi.org/10.1137/S003614450342480

Park, S., LiPuma, J. A., \& Prange, C. (2015). Venture capitalist and entrepreneur knowledge of new venture internationalization: A review of knowledge components. International Small Business Journal, 33(8), 901-928. https://doi. org/10.1177/0266242614526609

Pittaway, L., Robertson, M., Munir, K., Denyer, D., \& Neely, A. (2004). Networking and innovation: A systematic review of the evidence. International Journal of Management Reviews, 5(3-4), 137-168. https://doi.org/10.1111/j.14608545.2004.00101.x

Podolny, J. M. (2001). Networks as the pipes and prisms of the market. American Journal of Sociology, 107(1), 33-60. https://doi.org/10.1086/323038

Powell, W. W., White, D. R., Koput, K. W., \& Owen-Smith, J. (2005). Network dynamics and field evolution: The growth of interorganizational collaboration in the life sciences. American Journal of Sociology, 110(4), 1132-1205. https://doi. org/10.1086/421508

Pradhan, R. P., Arvin, M. B., Nair, M., Bennett, S. E., Bahmani, S., \& Hall, J. H. (2018). Endogenous dynamics between innovation, financial markets, venture capital and economic growth: Evidence from Europe. Journal of Multinational Financial Management, 45, 15-34. https://doi.org/10.1016/j.mulfin.2018.01.002

Prowse, S. (1998). Angel investors and the market for angel investments. Journal of Banking \& Finance, 22(6-8), 785-792. https://doi.org/10.1016/S0378-4266(98)00044-2

Pruthi, S., \& Wright, M. (2019). Social ties, prior experience, and venture creation by transnational entrepreneurs. International Journal of Entrepreneurship and Small Business, 36(1-2), 41-73. https://doi.org/10.1504/IJESB.2019.096964 
Que, J., \& Zhang, X. (2020). The role of foreign and domestic venture capital in innovation: Evidence from China. Accounting \& Finance, 60, 1077-1110. https://doi. org/10.1111/acfi.12401

Reverte, C., \& Badillo, R. (2019). Alternative equity financing instruments for entrepreneurial ventures: a bibliometric analysis of research in the last three decades. CURRENT SCIENCE, 116(6), 926-935. https://doi.org/10.18520/cs/ v116/i6/926-935

Rizvi, S. A. R., \& Arshad, S. (2018). Stabilising economic growth through risk sharing macro instruments. The World Economy, 41(3), 781-800. https://doi.org/10.1111/ twec. 12513

Rossi, M., Festa, G., Devalle, A., \& Mueller, J. (2020a). When corporations get disruptive, the disruptive get corporate: Financing disruptive technologies through corporate venture capital. Journal of Business Research, 118, 378-388. https://doi. org/10.1016/j.jbusres.2020.07.004

Rossi, M., Festa, G., Fiano, F., \& Giacobbe, R. (2019a). To invest or to harvest? Business Process Management Journal, 26(5), 1-25. https://doi.org/10.1108/BPMJ-052019-0204

Rossi, M., Festa, G., Papa, A., Kolte, A., \& Piccolo, R. (2020b). Knowledge management behaviors in venture capital crossroads: A comparison between IVC and CVC ambidexterity. Journal of Knowledge Management, 24(10), 2431-2454. https:// doi.org/10.1108/JKM-05-2020-0328

Rossi, M., Festa, G., Papa, A., \& Scorrano, P. (2019b). Corporate venture capitalists' ambidexterity: Myth or truth? IEEE Transactions on Engineering Management, pp.1-12. https://doi.org/10.1109/TEM.2019.2903984

Rossi, M., Festa, G., Solima, L., \& Popa, S. (2017). Financing knowledge-intensive enterprises: evidence from CVCs in the US. The Journal of Technology Transfer, 42(2), 338-353. https://doi.org/10.1007/s10961-016-9495-2

Rossi, M., \& Martini, E. (2019). Venture capitalists and value creation: the role of informal investors in the growth of smaller European firms. International Journal of Globalisation and Small Business, 10(3), 233-247. https://doi.org/10.1504/ IJGSB.2019.100123

Sahlman, W. A. (1990). The structure and governance of venture-capital organizations. Journal of Financial Economics, 27(2), 473-521. https://doi.org/10.1016/0304405X(90)90065-8

Samila, S., \& Sorenson, O. (2011). Venture capital, entrepreneurship, and economic growth. The Review of Economics and Statistics, 93(1), 338-349. https://doi. org/10.1162/REST_a_00066

Saxenian, A., \& Li, C.-Y. (2003). Bay-to-bay strategic alliances: the network linkages between Taiwan and the US venture capital industries. International Journal of Technology Management, 25(1-2), 136-150. https://doi.org/10.1504/ IJTM.2003.003094

Scheela, W., Isidro, E., Jittrapanun, T., \& Trang, N. T. T. (2015). Formal and informal venture capital investing in emerging economies in Southeast Asia. Asia Pacific Journal of Management, 32(3), 597-617. https://doi.org/10.1007/s10490-0159420-5 
Schneider, J. W. (2009). An outline of the bibliometric indicator used for performancebased funding of research institutions in Norway. European Political Science, 8(3), 364-378. https://doi.org/10.1057/eps.2009.19

Shane, S., \& Stuart, T. (2002). Organizational endowments and the performance of university start-ups. Management Science, 48(1), 154-170. https://doi. org/10.1287/mnsc.48.1.154.14280

Song, K., Kim, I., \& Chang, Y. K. (2014). A reverse takeover as an exit strategy of venture capital: Korean evidence. Pacific-Basin Finance Journal, 29(C), 182-198. https:// doi.org/10.1016/j.pacfin.2014.04.003

Sonne, L. (2012). Innovative initiatives supporting inclusive innovation in India: Social business incubation and micro venture capital. Technological Forecasting and Social Change, 79(4), 638-647. https://doi.org/10.1016/j.techfore.2011.06.008

Sorenson, O., \& Stuart, T. E. (2001). Syndication networks and the spatial distribution of venture capital investments. American Journal of Sociology, 106(6), 1546-1588. https://doi.org/10.1086/321301

Stokols, D., Hall, K. L., Taylor, B. K., \& Moser, R. P. (2008). The science of team science: Overview of the field and introduction to the supplement. American Journal of Preventive Medicine, 35(2), S77-S89. https://doi.org/10.1016/j. amepre.2008.05.002

Stuart, T. E., Hoang, H., \& Hybels, R. C. (1999). Interorganizational endorsements and the performance of entrepreneurial ventures. Administrative Science Quarterly, 44(2), 315-349. https://doi.org/10.2307/2666998

Suzuki, K.-i., Kim, S.-H., \& Bae, Z.-T. (2002). Entrepreneurship in Japan and Silicon Valley: A comparative study. Technovation, 22(10), 595-606. https://doi. org/10.1016/S0166-4972(01)00099-2

Tang, M. C., \& Chyi, Y. 1. (2008). Legal environments, venture capital, and total factor productivity growth of Taiwanese industry. Contemporary Economic Policy, 26(3), 468-481. https://doi.org/10.1111/j.1465-7287.2008.00105.x

Tenca, F., Croce, A., \& Ughetto, E. (2018). Business angels research in entrepreneurial finance: A literature review and a research agenda. Journal of Economic Surveys, 32(5), 1384-1413. https://doi.org/10.1111/joes.12224

Timmons, J. A., \& Bygrave, W. D. (1986). Venture capital's role in financing innovation for economic growth. Journal of Business Venturing, 1(2), 161-176. https://doi. org/10.1016/0883-9026(86)90012-1

Ueda, M. (2004). Banks versus venture capital: Project evaluation, screening, and expropriation. The Journal of Finance, 59(2), 601-621. https://doi.org/10.1111/ j.1540-6261.2004.00643.x

Uzuner, S. (2008). Multilingual scholars' participation in core/global academic communities: A literature review. Journal of English for Academic Purposes, 7(4), 250-263. https://doi.org/10.1016/j.jeap.2008.10.007

Van Eck, N. J., \& Waltman, L. (2010). Software survey: VOSviewer, a computer program for bibliometric mapping. Scientometrics, 84(2), 523-538. https://doi. org/10.1007/s11192-009-0146-3

Van Eck, N. J., \& Waltman, L. (2013). VOSviewer manual. Leiden: Univeristeit Leiden, $1(1), 1-53$. 
Van Eck, N. J., \& Waltman, L. (2014). Visualizing bibliometric networks. In Y. Ding, R. Rousseau, \& D. Wolfram (Eds.), Measuring scholarly impact (pp. 285-320). Cham: Springer International Publishing. https://doi.org/10.1007/978-3-31910377-8_13

Van Leeuwen, T. N., Moed, H. F., Tijssen, R. J., Visser, M. S., \& Van Raan, A. F. (2001). Language biases in the coverage of the Science Citation Index and its consequencesfor international comparisons of national research performance. Scientometrics, 51(1), 335-346. https://doi.org/10.1023/A:1010549719484

Van Nunen, K., Li, J., Reniers, G., \& Ponnet, K. (2018). Bibliometric analysis of safety culture research. Safety Science, 108, 248-258. https://doi.org/10.1016/j. ssci.2017.08.011

Van Raan, A. F. (2005). For your citations only? Hot topics in bibliometric analysis. Measurement: Interdisciplinary Research and Perspectives, 3(1), 50-62. https:// doi.org/10.1207/s15366359mea0301_7

Waltman, L. (2016). A review of the literature on citation impact indicators. Journal of Informetrics, 10(2), 365-391. https://doi.org/10.1016/j.joi.2016.02.007

Wang, C. K., \& Ang, B. L. (2004). Determinants of venture performance in Singapore. Journal of Small Business Management, 42(4), 347-363. https://doi.org/10.1111/ j.1540-627X.2004.00116.X

Wang, J.-C., \& Tsai, K.-H. (2005). Development strategies and prospects for Taiwan's R\&D service industry. International Journal of Technology Management, 29(34), 308-326. https://doi.org/10.1504/IJTM.2005.006013

Wang, J., Veugelers, R., \& Stephan, P. (2017). Bias against novelty in science: A cautionary tale for users of bibliometric indicators. Research Policy, 46(8), 1416-1436. https://doi.org/10.1016/j.respol.2017.06.006

Wang, K., Wang, C. K., \& Hu, C. (2005). Analytic hierarchy process with fuzzy scoring in evaluating multidisciplinary $\mathrm{R} \& \mathrm{D}$ projects in China. IEEE Transactions on Engineering Management, 52(1), 119-129. https://doi.org/10.1109/ TEM.2004.839964

Wang, Q. S., Anderson, H., \& Chi, J. (2018). VC political connections and IPO earnings management. Emerging Markets Review, 35, 148-163.

White, H. D. (2001). Authors as citers over time. Journal of the American Society for Information Science and Technology, 52(2), 87-108. https://doi.org/10.1002/10974571(2000)9999:9999\%3C::AID-ASI1542\%3E3.0.CO;2-T

White, S., Gao, J., \& Zhang, W. (2005). Financing new ventures in China: System antecedents and institutionalization. Research Policy, 34(6), 894-913. https://doi. org/10.1016/j.respol.2005.04.002

Wonglimpiyarat, J. (2013). The role of equity financing to support entrepreneurship in Asia: The experience of Singapore and Thailand. Technovation, 33(4-5), 163171. https://doi.org/10.1016/j.technovation.2012.12.004

Wonglimpiyarat, J. (2016). Exploring strategic venture capital financing with Silicon Valley style. Technological Forecasting and Social Change, 102, 80-89. https:// doi.org/10.1016/j.techfore.2015.07.007 
Wood, G., \& Wright, M. (2009). Private equity: A review and synthesis. International Journal of Management Reviews, 11(4), 361-380. https://doi.org/10.1111/j.14682370.2009.00264.x

Wright, M., Lockett, A., \& Pruthi, S. (2002). Internationalization of Western venture capitalists into emerging markets: Risk assessment and information in India. Small Business Economics, 19(1), 13-29. https://doi.org/10.1023/A:1015729430581

Wright, M., Pruthi, S., \& Lockett, A. (2005). International venture capital research: From cross-country comparisons to crossing borders. International Journal of Management Reviews, 7(3), 135-165. https://doi.org/10.1111/j.14682370.2005.00113.x

Wright Robbie, M., Ken. (1998). Venture capital and private equity: A review and synthesis. Journal of Business Finance \& Accounting, 25(5-6), 521-570. https:// doi.org/10.1111/1468-5957.00201

Yang, L., Chen, Z., Liu, T., Gong, Z., Yu, Y., \& Wang, J. (2013). Global trends of solid waste research from 1997 to 2011 by using bibliometric analysis. Scientometrics, 96(1), 133-146. https://doi.org/10.1007/s11192-012-0911-6

Yoshikawa, T., Phan, P. H., \& Linton, J. (2004). The relationship between governance structure and risk management approaches in Japanese venture capital firms. Journal of Business Venturing, 19(6), 831-849. https://doi.org/10.1016/j. jbusvent.2003.06.004

Zhang, J., Wong, P. K., \& Ho, Y. P. (2016). Ethnic enclave and entrepreneurial financing: Asian venture capitalists in Silicon Valley. Strategic Entrepreneurship Journal, 10(3), 318-335. https://doi.org/10.1002/sej.1230

Zheng, T., Wang, J., Wang, Q., Nie, C., Shi, Z., Wang, X., \& Gao, Z. (2016). A bibliometric analysis of micro/nano-bubble related research: Current trends, present application, and future prospects. Scientometrics, 109(1), 53-71. https:// doi.org/10.1007/s11192-016-2004-4

Zhu, J., Hu, G., \& Liu, W. (2019). DOI errors and possible solutions for Web of Science. Scientometrics, 118(2), 709-718. https://doi.org/10.1007/s11192-018-2980-7

Zhu, X., Turney, P., Lemire, D., \& Vellino, A. (2015). Measuring academic influence: Not all citations are equal. Journal of the Association for Information Science and Technology, 66(2), 408-427. https://doi.org/10.1002/asi.23179

Zider, B. (1998). How venture capital works. Harvard Business Review, 76(6), 131-139. 